University of Rhode Island

DigitalCommons@URI

Open Access Master's Theses

1979

\title{
INSTITUTIONAL GROWTH IN A RESIDENTIAL AREA: A CASE STUDY OF HARTFORD HOSPITAL
}

Donald Joseph Smyth

University of Rhode Island

Follow this and additional works at: https://digitalcommons.uri.edu/theses

\section{Recommended Citation}

Smyth, Donald Joseph, "INSTITUTIONAL GROWTH IN A RESIDENTIAL AREA: A CASE STUDY OF HARTFORD HOSPITAL" (1979). Open Access Master's Theses. Paper 523.

https://digitalcommons.uri.edu/theses/523

This Thesis is brought to you for free and open access by DigitalCommons@URI. It has been accepted for inclusion in Open Access Master's Theses by an authorized administrator of DigitalCommons@URI. For more information, please contact digitalcommons-group@uri.edu. 


\section{INSTITUTIONAL GROWTH}

IN A

RESIDENTIAL AREA:

A CASE STUDY OF HARTFORD HOSPITAL

BY

DONAID JOSEPH SMYTH

A THESIS PROJECT SUBMITTED IN PARTIAI FULFILIMENT OF THE REQUIREMENTS FOR THE DEGREE OF

MASTER OF COMMUNITY PLANNING

UNIVERSITY OF RHODE ISIAND

1979 


\title{
MASTER OF COMMUNITY PLANNING THESIS PROJECT OF \\ DONALD JOSEPH SMYTH
}

Approved :

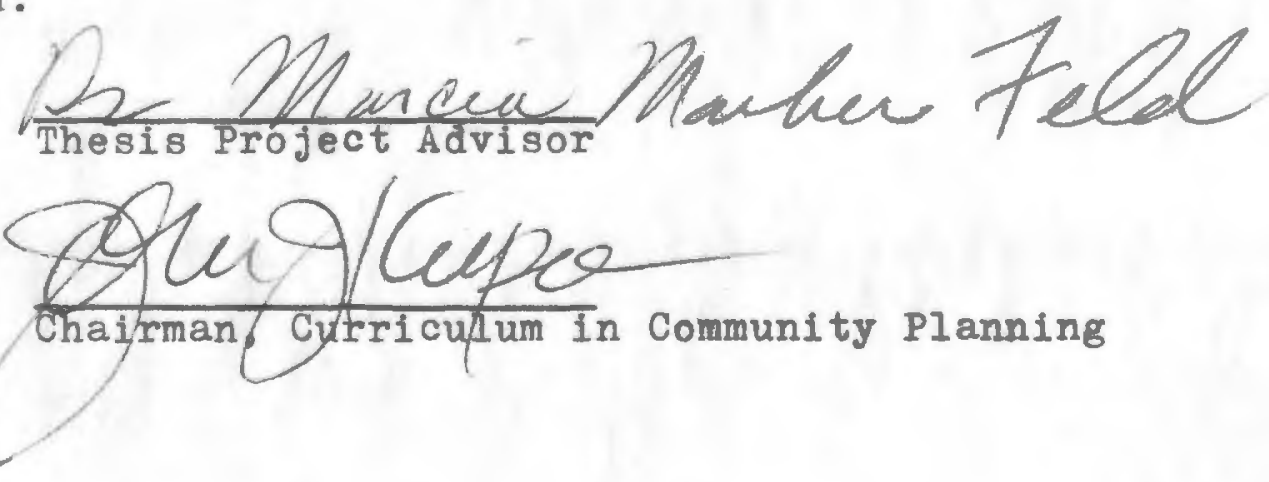

\author{
UNIVERSITY OF RHODE ISILAND
}

1979 


\section{ACKNOWLEDGMENTS}

This project would not have been possible without the support and help of many people. I would like to take the opportunity to thank them now. Special thanks go to my parents who have seen me through many trials and tribulations in the past years. And finally, I would like to thank Joan. Her patience and encouragement kept me going to see this thing through. Thanks. 
TABLE OF CONTENTS

page

Introduction ................. 1

Chapter 1 Statement of the Problem . . . . . 4

Chapter 2 Population and Housing Characteristics of the Study Ne1ghborhood: The South

Green Area .......... 17

Chapter 3 Residential and Business Displacement 39

Chapter 4 Hospital Planning at the Federal, State and Local Level ... . . . 65

Chapter 5 Conclusion and Recommendations . . 80 Appendixes

A. A Chronology of Communications and Letters Pertaining To This Study ........

B. Table of Tax-Exempt Property Owned By the Hospital . . . . . . . ... . . 99

Bibliography . . . . . . . . . . . 101 


\section{LIST OF TABLES}

Table

page

1. Age Characteristics . . . . . . . . 18

2. Ethnic Distribution In The South Green Neighborhood. . . . . . . . . . . 19

3. Kinse1la School Statistics, 1964 thru 1978 . 20

4. Median Family Income. . . . . . . . . . 22

5. Industry Employed . . . . . . . . . . . 23

6. Occupation 1970 ............ 24

7. Percentage Breakdown of the Professional, Technical \& Kindred, and Service Occupations 25

8. Means of Transportation to Work, 1970 . . . 26

9. Number of Dwelling Units . . . . . . . 27

10. Number of Dwelling Units In 1979. . . . . 28

11. Units in Structure.............. 28

12. Percentage of Owner Occupied Dwellings. . . 29

13. Composite Blight Index by Neighborhood. . . 32

14. Year Moved Into Unit . . . . . . . . . 34

15. Median Contract Monthly Rent. . . . . . 35

16. Housing Units for Rent Or Sale. . . . . . 36

17. Privately Owned Vacant \& Abandoned Structures In Hartford. . . . . . . . . . . . . 4 43 


\section{LIST OF MAPS}

Map I: Location of Hartford Hospital and the
Study Area . . . . . . . . . . 3
Map II: KInsella School District and Study Area 21
Map III: Neighborhood Map............ 33 


\section{INTRODUCTION}

Hartford Hospital is a major health institution situated approximatley one mile from the downtown area. It is the second largest hospital in New England. The Hospital enfoys a solid reputation for providing medical care for thousands in the Greater Hartford Area.

The need to retain this status has required the Hospital to improve upon their facilities, add new equipment and provide other amenities that attract competent people to their staff. One of the amenities it provides is free parking to its employees.

As the Hospital grew, it became evident to administrators that more parking would have to be provided. A serlous shortage in spaces has developed. To alleviate the situation, the Hospital purchased a number of housing structures and removed them, so that parking lots could be created.

Overall, this paper deals specifically with the issues of institutional expansion and displacement. Directly pertaining to these issues is the 1 dea of resident involvement in the Hartford Hospital planning process. Hospital officials do not feel that neighborhood residents are qualified to help them plan.

Chapter one is a description of the problem, and how residents have become involved in the issues of displacement and the Hospital's expansion. Chapter two describes the physical, social and economic characteristics of the nelghborhood. The third chapter defines what displacement is, 
what types of displacement exist, and how it effects the individual. Chapter four is an outline of the attempts at controlling hospital expansion at the federal, state, and local levels. The final chapter contains the conclusions and recommendations of this report. 

Map I: Location of Hartford Hospital and the Study Area

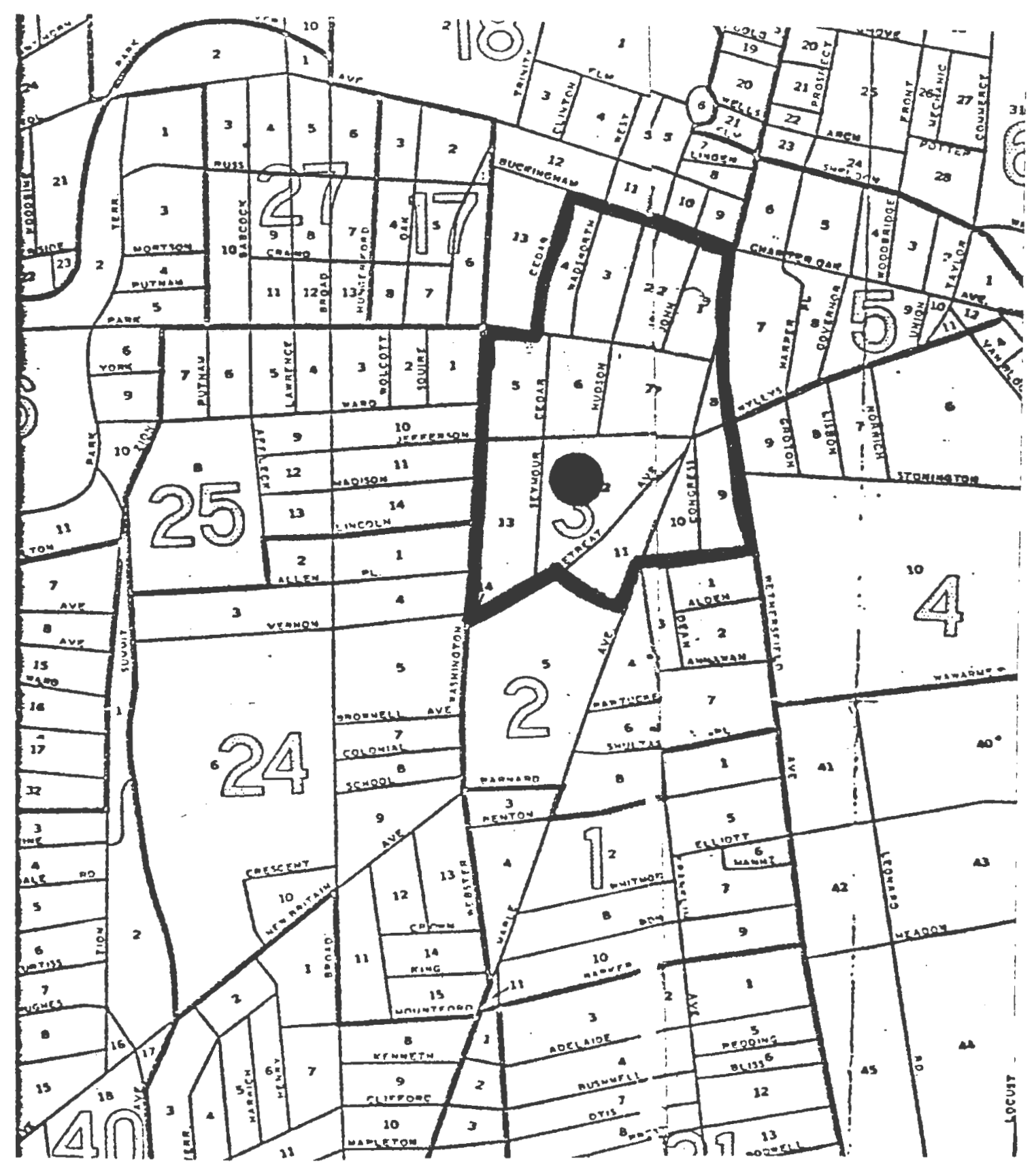

Study Area

Hartford Hospital 
CHAPTER 1

STATEMENT OF THE PROBLEM

Hartford Hospital's expansion has been taking place for many years. Until recently, little attention has been drawn toward this issue. From 1950 to 1978, the Hospital acquired and demolished 37 housing structures which were once 2, 3 and 6 family dwellings. In January of this year, two buildings containing 21 units were razed. In the spring of 1978, through its wholly owned subsidiary, the Jefferson Street Medical Building, Inc., the Hospital sent out notices of eviction to the occupants of 94-98 Jefferson Street. 1

The occupants of the building's five apartments and three retail stores were forced to move. A few of the tenants upset at the news, vowed to fight the Hospital. Joe Bascetta owned a shoe store at 94 Jefferson and Mat Tallow lived on the second floor of 98 Jefferson. Both men were angered at the seemingly helpless position in which they were being placed by the Corporation. The question which entered their minds was how they were going to fight a large institution like the Hospital. The power and money of a multi-million dollar operation such as the Hospital, would be a formidable opponent to attack. Tallow decided that the omly way to stop expansion would be to form a coalition of residents in the area that could voice opposition to the Hospital's policy of destroying the neighborhood. He succeeded in calling a meeting that was attended by about 20 residents who shared the same concern. 
What eventually emerged was the establishment of the Jefferson-Seymour-Hudson-Retreat Neighbors, a block club that is part of Hartford Areas Rally Together (HART). 2

Hartford Hospital acquired 98 Jefferson Street with the intention of demolishing it to create needed parking spaces for their employees. The Hospital employs approximately 4,000 people and has had a parking problem for a number of years. There is a three year waiting period for the 1,400 or so parking spaces that now exist. 3

Also $j$ oining the campaign to save the building was the Hartford Architectural Conservancy (HAC). The Conservancy, a non-profit corporation in existence since 1973, has made a sizeable impact on the preservation and reuse of architecturally and historically significant structures. They were instrumental in saving 75 buildings from demoIition in the Charter-Oak-South Green area, part of which is contained in the study neighborhood. The City had been prepared to demolish all the buildings located along Congress Street, the buildings on the west side of Wethersfield Avenue between Wyllys Street and Morris Street, and along Morris Street itself. The Conservancy convinced the City of the usefulness in saving these housing structures. Widespread displacement was inevitable regardless of which alternative was followed, resulting in relocation of the inhabitants of 200 dwelling units. Federal relocation funds were provided for the residents.

HAC felt that saving 98 Jefferson was imperative. 
They saw the proposed demolition as part of an incremental process that would eventually have negative side effects on the neighborhood. It was submitted that the building could be renovated for a cost of $\$ 300,000$. "Because renovation costs are so high, and because builaing codes require costly energy-saving installations, it would not be feasible to use the restored building for low-income housing or inexpensive rents for small businesses." 4 Due to neighborhood pressure and the Conservancy's concern for historic preservation, the Hospital has agreed not to demolish 94-98 Jefferson and plans to rehabilitate the building. As the negotiations took place, the occupants were being forced to move.

Howard Henrikson, manager of all of Hartford Hospital's residential properties, proceeded with the eviction process. 5 Matt Tallow and Joe Bascetta, who had rowed to stay, were forced to leave in August, after coutt ordered eviction notices were served. The following guote sums up Joe Bascetta's feelings:
"Pelican Footware has now relocated to Park Street, next to the old Iyric Theatre. Joe Bascetta is still bitter about his experience. "What do you say about people who woulan't even help anybody relocate? They didn't even help the old man on the third floor who had lived there for 30 years. Me, I would have stayed if I could. I told them, you can renovate around me, and I'll renovate my place. I even told them they could raise my rent; I'd work out any possibility. But no, it was always like the men with the ball and chain were waiting around the corner. Now they're saving $1 t . .$. One of the tenants, Iucien Florist, is not bitter 
about the eviction. The Hospital offered the business a new location in a building they owned at 110 Jefferson Street. When the Hospital purchased the building they had evicted tenants in six apartments above the store so that Hospital employees could ocoupy them. The building is unoccupled to date. Hartford Hospltal's policy is to occupy all of their residential property with their employees. This policy did not preclude the demolition of two Hospital owned buildings on 151-157 Retreat Avenue. The tenants, all Hospital employees, were given eviction notices in the summer of 1978. Therbulldings were razed to create 93 parking spots, "displacing the Hospital employees who, when they lived in the buildings' 21 units, could walk to work."7

The Seymour-Jefferson-Hudson-Retreat Neighbors have managed to bring their plight to the public. Local newspapers have carried articles on the Hospital's expansion. The issue has also been submitted as a resolution at the HART Community Congress that was attended by many City residents and officials.

On February 16th, 1979, a resolution was passed by the Hartford City Council. The resolution read as follows:

This is to certify that at a recessed meeting of the Court of Common Council, February 16, 1979, the following resolution was passed. WHEREAS: Expansion of major institutions can have a major impact on adjacent neighborhoods; and

WHEREAS, Some institutions in Hartford such as hospitals and colleges have recently made physical development decisions of significant impact on neighbovhood near these institutions; and WHEREAS, Cities such as San Prancisco and Boston 
have adopted various procedures to insure that institutional expansion does not have negative impact, such as ordinances requiring institutional master plans governing expansion and zoning for new uses; now, therefore, be it

RESOIVED: The the City Manager and the Commission on the City Plan be requested to investigate the use and effectiveness of these and other tools as to their applicability to Hartford's neighborhoods and institutions.

The group generated more publicity on the issue by holding a press conference on February 17th, 1979, across the street from the Hospital. With reporters taking notes and cameras on, residents outlined the problems they faced with the Hospital. They carried gigns and chanted "What's next to go, we want to know." The group marched to the main entrance of the Hospital, attaching a letter to the door, addressed to the president and other officers of the institution. The letter reflected the insecure feeling that residents were developing toward their neighborhood. They wanted control over future changes in the area.

In October of 1978, Paul Somoza, Planning Director for the Hospital, stated that there were no plans. To quote Mr. Somoza, "We have no plans for the neighborhood. It's not our neighborhood, and we shouldn't be planning for 1t." 8 The letter on the door outlined what had happened since that statement. 9

1) In January the Hospital demolished 151-157 Retreat Avenue. A loss of 21 housing units and $\$ 8,000$ in tax revenue.

2) On January 21, 1979, the Hospital purchased 11 Seymour street and has told one of the six tenants they will be evicted by April 1 st. The Hospital plass to demolish 11 seymour St. 
3) The Hospital has yet to tell the neighborhood if it plans to rehabilitate 98 Jefferson St. since it evicted its tenants

4) The Hospital slready owns over $\$ 30$ million worth of "tax-exempt" property.

5) A model of the Hospital's future plans for the neighborhood reveals more parking lots for the neighborhood and the closing of seymour street.

The letter also contained a quote from the Hospital Bulletin dated June 1978. The letter says in part, "We are in the South End to stay...the survival, safety, and concern to us... whether the issue is parking, housing, or security we have a stake in the upgrading of our propery and its neighborbood...We must keep lines of communication open with the public." The letter goes on to say that Mr. Somoza had misinformed residents about Hospital plans, refused support for increased public safety in the area, and that increased speculation in the area as a result of Hospital activities has led to residential insecurity.

The residents requested a meeting with the officers and Board of Directors of Hartford Hospital to ask the following questions:

1) Will the Hospital reveal their plans for the neighborhood, including: - future land acquisition?

- the model plan for the neighborhood?

- the Jefferson St. Medical Building/ Hartford Hospital relationship? -future parking lote?

2) Will the neighborhood have input into the planning process for the future of the neighborhood?

3) Will the Hospital give us a written guarantee that 98 Jefferson will be rehabilitated?

4) Will the Hospital reveal the future of 11 Seymour Street, and,

- the future repairs and maintenance of 
any occupied Hartford Hospital owned property.

- the future relocation of tenants displaced by Hartford Hospital?

5) Will the Hospital support other neighborhood issues such as housing, security, traffic safety, and owner-occupancy?

John Springer, President of Hartford Hospital agreed to meet in an open, public meeting at the Hospital. It was set for March 13th, 1979.

The meeting proved to be unproductive for the neighborhood residents. Residents of 11 Seymour complained bitterly about the poorly mainteined structure they lived in. The building, a brick three story tenament, is surrounded by a huge parking garage and parking lots. Tenants pressed Springer and Somoza for answers on what was planned for the future of 11 Seymour. Hospital officials responded that the building would be maintained indefinitely. Residents were perturbed at what they felt was an inadequate response. It seemed probable that the building, which stands as an island in a vast parking lot (that was once a neighborhood) would eventually come down. The residents were uneasy over not knowing the Hospital's plans for the future. Springer denied the Hospital had any plans. In March of 1967, a study by Doxiadis Associates, Inc, was commissioned by Hartford Hospital, the Institute of Living, and Trinity College. ${ }^{10} \mathrm{Mr}$. Springer had mentioned this study at the meeting, but passed it off as outdated. The plan mentions the closing of seymour street and the realignment of Retreat Avenue in an unspecified way. 
Complaints of uncertainty are not limited to just residents of the area. Mr K, who owns a sandwich shop across the street form the Hospital also expressed concern at the meeting. His business is located in a building owned by the Hospital. Mr K told Springer and Somoza that the Hospital is not holding to the conditions set in the lease. He sald that he liked to keep a clean place but was hampered by the Hospital's neglect in maintaining the property.

At one point in the meeting, the Hospital expressed concern about the conditions and safety of the neighborhood. Paul Somoza stated that because Hartford Hospital is in competition with surrounding hoapitals, it was important for them to maintain a safe and clean environment to attract patients and visitors. Mr. K responded by saying that if the Hospital was so concerned, why didn't they keep their property in proper condition. The Hospital, he felt, was the cause of the whole problem.

The next question raised was whether the Hospital would develop a five year plan. Residents were told that they would be informed when such a plan was developed. The residents wanted more. To quote Carol Murphy, a resident of the area, "We don't want to be informed, we want to work with the Hospital." 11 Mr. Springer mentioned that it had taken the Hospital two years to go through a formel planning structure for the rehabilitation of one of the Hospital's wings; if an informal process would take more time, then it wouldn't be worth 1t. He felt that best they 
could do was tu inform everyone o" their objectives.

The idosoital, in conjunction with the Institute of -iving and rrinity uldege are presentjy in the process of conducting $a$ survey of their employees. The survay is to determine if emplnyees would be willing to movs into the area around the iristitutions. Nr. Somoza felt thit employens living near the $\mathrm{H}_{0}$ spital woul l help to alleviate some of the pressure for increased parking, as well as stabilize the neighborhood. The Hospital is hesitant about allowing neighborhood residents see the results. One resident pointej out that such a survey could cause increased speculatior. in the area, resulting in more nejghborhood instability and displacement.

Mr. Springer wild not make any committments when asked for the Hnspital's support for more police protection and traffic control. The Hospital's reluctance to work with residents on the issues mentioned has left the neighborhood angry. They nave vowed to fight for more answers. i case that closely parallels the Hartiord Hospital expansion issue took place in Boston. 12 In 1964, red] estate agents of Harvard Medical School began buying up property in a Roxbury neighborhood, to build a new hospital compl. called the Affiliated Hospitals center (Hov). The neighourhood they were investing in contained mostly two and three family dwellings, the majority of which were owner gurvied. The community was made up of Irish Catholics, Gomans, and a smaller amount of Black and Spanish-speaking families. Many people had grown up in 
the neighborhood and had set up households near their relatives and friends." 13

Harvard began a policy of renting to students and young staff members instead of families. These new residents had no ties to the neighborhood. Harvard continued to purchase property in the area. They managed their property poorly and raised rents, forcing many families to move. Plans to build the Affiliated Hospital Center were announoed in 1968, and by 1971 the school had decided to eliminate 182 apartments.

In 1969, the Roxbury Tenants of Harvard Association (RTH) was formed. Impetus for the formation of the Association came as a result of a student strike at Harvard over the School's policy of destroying houring. The RTH presented Harvard with a petition that stated the tenants' requested that the proposed hospital facility be located elsewhere. After much pressure and publicity, the University announced that they would build 1,100 units of new housing, part of which would serve to house those displaced by AHC. Tenants were not consulted about their needs.

After the housing plans were announced, the University formed several committees made up of tenants, students and health workers. The committees as it turned out, were ineffective in dealing with the hospital expansion issue or housing police. "Actual decision-making power stayed in the hands of the Harvard Corporation and high level administrators." 14 
In the meantime, the RTH, which had picked up momentum and now included most of the families in the neighborhood, was increasingly becoming frustrated in their attempts to deal with the university. As a result the association staged a "mill-1n" at the Dean of the medical school's office, involving over 100 participants which included students and faculty supporters. The group asked the Dean to visit the neighborhood to see the housing deterioration. Further, the association utilized the media extensively to bring pressure on the university. "The Harvard Administration, headed by a new president, became convinced that the tenants' commitment and power base were strong enough that they had to be taken seriously." 15

Since 1970, the Harvard Corporation has assigned one of its members and a staff person to work directly with the neighborhood people in negotiating agreements between the two groups. A decision by the hospital to roll back and freeze rents at their 1969 level was attained. In 1971, the Corporation promised in writing that no tenants would be evicted until suitable relocation housing was available and approved by the RTH. In 1975, an agreement was reached concerning the development of tenant controlled mixed income housing. RTH was made the legal co-developer, putting them in partial control of architectural plans, rental policies and maintenance. Ground breaking for the construation took place in October on 1975.

This chapter has served to outline the problems faced 
by residents in the Hart"ord Hospital arra. Funomost has been the displarment of rewdents and businesses ir iho neighborhosd. Unapter II will prvide a socizeconomi. description of the neighborhood, ard its relationstip $\ldots$ the City and the metropolitar area. 
Footnotes: Chapter 1

${ }^{1}$ Pat Courtney, "Hospital Parking Pressures Neighborhood", Southside Neighborhood News (Oct. 18-Nov. 1, 1978) p. 2 .

${ }^{2}$ G.A.R.T. (Hartford Areas Rally Together) is a grassroots community organization based in the Southend of Hartford. Established in 1975, H.A.R.T. has organized seven neighborhoods and one Hispanic group aroind community and self interest needs and issues.

${ }^{3}$ Nancy Pappas, "Hospital Parking Solution Out of Sight", The Hartford Courant (Oct. 29, 1978) p. 31.

${ }^{4}$ Courtney, p. 2 .

${ }^{5}$ Ibid., p. 2.

${ }^{6}$ Ibid., p. 2 .

Pappas, p. 31

${ }^{8}$ Courtney, p. 3 .

Ietter to the Hartford Hospital Board of Directors, Dated Feb. 17, 1979.

${ }^{10}$ Doxiadis Associates, Inc., The Trinity Community: Peasability Studies For Area Improvement, Prepared For Trinity College, The Harfford Hospital and the Institute of Ilving (Washington D.C., March 1967)

${ }^{11}$ Interview with Carol Murphy, April 3, 1979.

12 Howard Waitzkin and John A. Sharratt, "Controlling Medical Expansion", Society Magazine (Jan.-Feb. 1977)

$$
\begin{aligned}
& { }^{13} \text { Ibid., p. } 30 . \\
& { }^{14} \text { Ibid., p. } 31 . \\
& { }^{15} \text { Ibid., p. } 31 .
\end{aligned}
$$


POPUIATION AND HOUSING CHARACTERISTICS

OF THE STUDY AREA:

THE SOUTH GREEN NEIGHBORHOOD

The number of residents in the City of Hartford, as is true in most Northeastern Cities, has declined since 1950. The population has dropped from 177,397 people in 1950 to 158,017 in 1970, representing a total change of 10.9\%. The South Green nelghborhood on which this study focuses, has also experlenced population decline." The relative percentage losses have been considerable when compared with the City as a whole. From 1950 to 1970 the neighborhood has lost $30.5 \%$ of its residents.

Population losses in this neighborhood and in the City can be attributed to two causes: 1) outmigration of the population has occurred in the area, or 2) the death rate has exceeded the birth rate. In this case, the losses in population can be explained by the outmigration of people from the neighborhood. Table 1 on the following page 11lustrates in which age groups the greatest population losses has occurred.

* study neighborhood, study area, and nelghborhood are used interchangeably and refer to the South Green neighborhood. 


\begin{tabular}{|c|c|c|c|c|c|c|}
\hline \multirow[b]{2}{*}{ Age } & \multicolumn{2}{|c|}{1950} & \multicolumn{2}{|c|}{1960} & \multicolumn{2}{|c|}{1970} \\
\hline & C1ty & $\begin{array}{l}\text { Study } \\
\text { Area }\end{array}$ & City & $\begin{array}{l}\text { Study } \\
\text { Area }\end{array}$ & City & $\begin{array}{l}\text { Study } \\
\text { Area }\end{array}$ \\
\hline under 5 & $9.1 \%$ & $7.5 \%$ & $10.4 \%$ & $7.0 \%$ & $9.2 \%$ & $9.8 \%$ \\
\hline 5 to 9 & 6.9 & 4.6 & 7.8 & 5.1 & 8.8 & 7.3 \\
\hline 10 to 14 & 5.3 & 4.4 & 6.9 & 4.9 & 8.0 & 6.0 \\
\hline 15 to 19 & 5.8 & 6.2 & 6.6 & 7.3 & 8.6 & 10.5 \\
\hline 20 to 24 & 8.1 & 9.6 & 7.4 & 10.0 & 10.8 & 15.6 \\
\hline 25 to 34 & 18.0 & 19.2 & 13.5 & 13.0 & 13.7 & 14.4 \\
\hline 35 to 44 & 15.1 & 15.0 & 13.2 & 12.9 & 9.8 & 8.0 \\
\hline 45 to 54 & 10.4 & 11.0 & 10.6 & 11.1 & 9.6 & 9.0 \\
\hline 65 \& over & 8.5 & 10.4 & 11.0 & 14.7 & 10.8 & 9.7 \\
\hline
\end{tabular}


In 1960 a loss in all categories was reported, except for the 65 and over cohort which increased by $8.8 \%$. The 1970 data shows an increase in the youth population resulting from in-migration. A considerable decline continued to take place in the population over 25 years of age.

\section{Ethnic Distribution}

Table 2 is used to illustratee the variety of etmic groups that reside in the study nelghborhood.

Table 2: Ethnic Distribution In The South Green Neighborhood 1960 1970

Black $0.8 \%$

$2.6 \%$

Puerto Rican

4.1 20.1

United Kingdom

3.3

0.6

Ireland

5.6

1.5

Nosway

Sweden

0.9

Germany

1.7

0.8

Poland

10.1

5.6

Greek

-

0.3

Austria

0.5

0.6

Hungary

0.4

USSR

1.8

$-$

Italy

10.6

1.0

Canada

11.3

2.4

Mexico

0.1

7.0

Source: U.S. Census for Hartford, 1960 and 1970. 
$50 \%$ of the population, with the other 50\% classified as native to this country. (It must be noted that the Black and Puerto Rican populations are still counted as separate groups because of racial and language characteristics.) The distribution changes dramatically with a large influx of Puerto Rican immigrants arriving in the area by 1970. A clearer trend of this immigration can be seen by the use of Hartford School Board statistics. The school Board map on the following page shows that much of the study area is contained within the Kinsella Schoold district. Table 3 illustrates the large migration of Hispanics into the area.

Table 3: Kinse1la School Statistics, 1964 thru 1978.

Year

Black

White

Hispanic

1964

13.9\%

$53.2 \%$

$32.9 \%$

1965

9.7

55.0

35.3

1966

7.0

51.1

41.2

1967

9.6

41.3

49.1

1968

11.7

37.9

50.3

1969

16.9

22.6

59.3

1970

24.3

16.5

59.1

1971

28.3

12.8

58.9

1972

28.2

1973

25.0

11.1

60.6

1974

24.5

9.5

65.5

1975

23.4

7.6

67.9

1976

22.6

6.2

70.4

1977

22.5

6.0

71.4

1978

20.8

4.0

73.3

4.9

74.3

Source: The Hartford Board of Education 



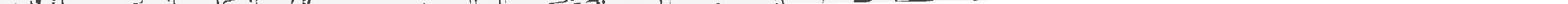


Income

The study neighborhood has not kept pace with the rising incomes of the City and the Greater Hartford Region as a whole.

Table 4: Median Family Income

$\begin{array}{lccc} & 1960 & 1970 & \text { क Change } \\ \text { Metropolitan } & \$ 7,187 & \$ 12,282 & 41.5 \% \\ \text { Hartford } & 5,990 & 9,108 & 34.2 \\ \text { Study Area } & 5,462 & 6,750 & 19.0\end{array}$

Source: U.S. Census for Hartford Connecticut, 1960 and

In 1960 and 1970 we can see that both the City and the neighborhood have median incomes that are lower than the metropolitan area. The median income for the nedghborhood was 26\% lower than that of the City, reflecting a generally disadvantaged population.

In $1969,24 \%$ of the families in the nelghborhood were classified as having incomes below the poverty level, compared to $12.6 \%$ for the City and $4.9 \%$ for the metropolitan area. 1 Board of Education figures for 1978 show that approximately $75 \%$ of the students enrolled at Kinsella School were eligible for Aid to Families with Dependent Children (AFDC), meaning that they were qualified for or were receiving public aid. 
Employment

It can be seen by Table 5 that the health services industry is the largest provider of jobs for the study area.

Table 5: Industry Emploxed

Employed

Study Area

Hartford

Metro 1960

1970

$1960 \quad 1970$

Area

Construc-

tion

$$
5.0 \%
$$

$4.3 \%$

$5.5 \%$

$7.4 \%$

1970

Manufacturing

31.2

19.5

30.1

26.0

$6.0 \%$

Comm.

Ut11. \&

Sanitary

2.1

4.2

2.0

2.3

2.2

Wholesale

1.5

3.2

3.4

3.5

4.2

Retall

11.6

14.4

13.0

13.6

14.8

Pinance,

Insurance \&

Real Estate

\begin{tabular}{l}
$-\quad 7.3$ \\
\hline
\end{tabular}

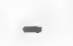

13.6

12.4

Business \&

Repair

3.1

2.4

3.3

2.3

3.0

Personal

Services

4.3

2.9

5.7

4.8

2.9

Health

Services

15.8

23.0

$4 \cdot 6$

6.6

5.5

Educational

Services

2.1

2.8

3.6

$5 \cdot 3$

7.6

Other Prof. Services

2.3

7.1

3.8

5.9

4.2

Public

Admin.

$$
2.4
$$

4.7

5.0

4.8

4.5

Others

16.8

4.3

18.8

1.7

1.9

Source: U.S. Census for Hartford Connecticut, 1960 and 1970

Hartford Hospital and the Institute of Ifving account for 
this large percentage. The manufacturing sector which employed $31.2 \%$ of the neighborhood work force in 1960, dropped to 19.5 on in 1970. s kecrease in the same sector can also be seen in the City-wide percentages, while an Increase ras taken place in the metropolitan area. These percentages coincide with the losses in manufacturing jobs that the City has been experiencing since 1950. Wany factories have decided to move to the outlying areas where land acquisition and taxes are less costly.'2 There has beer a regional trend for factories to relocate to the south and Southwestern parts of the country to take advantage of many things, among them cheaper labor costs and lower union activity. 3

The highest percentage of workers are concentrated in the professional and technical, operatives, clerical and service occupations.

Table 5: Occupation 1970

\begin{tabular}{|c|c|c|c|}
\hline occupation & $\begin{array}{l}\text { Study } \\
\text { Area }\end{array}$ & Hartford & $\begin{array}{l}\text { Wetro } \\
\text { srea }\end{array}$ \\
\hline Professional/Technical & $19.8 \%$ & $12.5 \%$ & $18.7 \%$ \\
\hline Nanager/Administrator & 3.0 & 4.0 & 8.5 \\
\hline Sales Worker & 5.7 & 5.5 & 7.7 \\
\hline Clerical & 14.5 & 24.0 & 23.0 \\
\hline Craftaman/Foreman & 9.4 & 12.5 & 13.6 \\
\hline Operatives (ex. Trans.) & 4.2 & 16.9 & 11.7 \\
\hline Transportation Oper. & 0.5 & 3.0 & 2.5 \\
\hline Laboren & 5.3 & 4.9 & 3.0 \\
\hline Farmwcrker & 2.7 & 0.4 & 0.7 \\
\hline service horker & 23.6 & 14.6 & 9.6 \\
\hline Private Household & 0.2 & 1.7 & 0.8 \\
\hline ource: U.S. Census for & Hart & nnecticu & \\
\hline
\end{tabular}


The following is a detailed analyses of the professional, technical and service occupations.

Table 7: Percentage Breakdown of the Professional, Techrical Kindred, ana Service Occupations

Percentage

in vategory

Professional, Technical \& Kindred

$$
\begin{array}{r}
45.26 \\
5.5
\end{array}
$$

-health workers

- teachers (elementary and secondary)

Service Workers

38.9

-cleaning, food service workers

1.9

- protective services

43.2

-personal, health service workers

jource: U.S. Census for Yartford Connecitcut, 1970.

Fealth workers in the professional/technical category are highly trained individuals such as doctors, nurses, pharmacists, dieticians, laboratory technicians and

physical therapists. This group makes up $4 \% 3 \%$ of the professional/technical occupations in the study area.

Service workers make up $23.5 \%$ of all occupations, this being the predominate employment category in the area. The service category can be broken down into clearing and food service workers, protective services, and personal and health service workers. Cleaning and food service workers include chambermaids, janitors, cooks, dishwashers, food counter workers and bartenters. This roup rakes up zo: of those pmploved as service workers. The personal and 
health subcategory makes up $43.2 \%$ of the service workers in the study area. Personal and health service workers include barbers, elevator operators, health aides (except nursing) as well as nursing aides, orderlies and attendants. In the case where jobs have shifted to ateas surrounding the City, residents in the study area are at a disadvantage because the majority lack transportation. Table 8 illustrates this disparity.

Table 8: Means of Pransportation to Work, 1970.

Transportation Type

CIty Study

Private Auto

-driver

46. $2 \%$

$30.7 \%$

- passenger

12.3

6.0

Bus

25.9

26.6

Train

Walked

13.3

34.8

Work at Home

1.2

0.8

other

1.1

1.1

Source: U.S. Census' for Hartford Connecticut, 1970.

Further, in $1970,61.6 \%$ of all occupied housing units in the study area did not have access to an automobile, as opposed to $15.5 \%$ Ctiy-wide and $14.7 \%$ in the metropolitan area. ${ }^{4}$ This wauld indicate that residents in the neighborhood are limited in the distance they can travel to find work. In $1970,59 \%$ of the workforce in the neighborhood held jobs in the City. ${ }^{5}$ 
Housing Units

The Bureau of Census defines housing units as all occupied units plus vacant units which are intended for tear-round use. Table 9 shows that from 1950 to 1960 there was an increase in the amount of housing units available in the neighborhood and the City, with the neighborhood increasing at a faster rate.

Table 9: Number of Dwelling Units.

$1950 \quad 1960$ \%Change 1970 \%Change

Study

Area 2,126 2,395 $+11,2 \%$ 2,066 $-13.7 \%$

City 52,429 57.653 $+9.0 \%$ 58,495 $+14.4 \%$

Source: U.S. Census for Hartford Connecticut, 1950, 1960 and 1970

However, by 1970 that growth trend had changed. The amount of housing units in the City had continued to increase (14.4\%) while the number of units in the neighborhood dropped by $13.7 \%$

A housing survey was taken to determine the number of housing units that exists in 1979. Housing units were determined by counting the number of mailboxes or door buzzers each structure had. The results, which are shown on the following page, indicate a considerable loss in housing units $(16.2 \%)$. Presently there is a shortage of housing for low-income families and individuals in the City. ${ }^{6}$ 
Table 10: Number of Dwelling Units In 1979

$1970 \quad 1979 \quad$ \&Change

Study

Area $\quad 2,066 \quad 1,732 \quad-16.2 \%$

Source: study area survey completed in Mar. 1979, and the U.S. Census for Hartiord Connecticut, 1970.

Types of Housing Structures

It has been reported that $40 \%$ of the City's housing stock consists of bulldings that contain more than six units. 7 The study nelghborhood, as can be seen by Table 11, has more than it's share of these multi-unlt buildings.

Table 11: Units In Structure

1960

1970

Number of

Study

Units/Struct. City Area

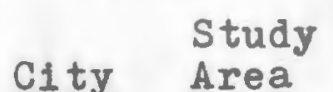

1 $17.2 \%$

$9.2 \%$

C1ty Area

2

13.2

6.0

$12.6 \%$

$0.8 \%$

$3 \& 4$

25.7

16.0

13.4

6.4

5 to 9

$20.3 \quad 27.3$

10 or more

23.6

41.5

$22.9 \quad 9.0$

Source: U.S. Census for Hartford Connecticut, 1960 and 1970.

From 1960 to 1970, there was a decrease in the number of ope, three and four unit housing structures in the study area. This change can be explained as a result of demolition and conversions. The Hospital itself has torn 
down 22 housing structures between 1950 and 1970.9 Most of these buildings were two, three, or six family dwellings. Some of the buildings in the area have been converted to rooming houses creating crowded conditions. The conversion of housing units to offices used for health related activities has also occurred.

The greater amount of large apartment buildings in the study area explains the low percentage of owner occupancy.

Table 12: Percentage of Owner Occupied Dwellings

Area $\quad 1950 \quad \underline{1960} \quad \underline{1970}$

Hartford $22.0 \% \quad 23.5 \% \quad 20.3 \%$

Study

Area

$\begin{array}{lll}7.6 & 5.7 & 3.5\end{array}$

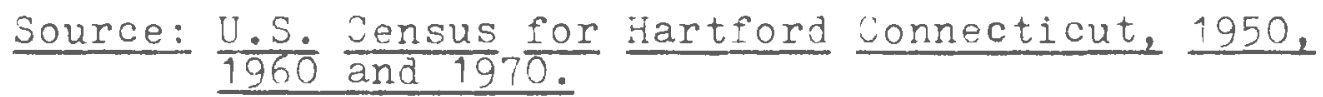

Owner occupincy is usually quite important to neighborhood stability. An owner who is living in the building is more apt to keep it in reasonable repair and more likely to be concerned with the overall changes in the area.

Housing Londitions

The housing stock in the neighborhood is ouite old. Statistics in 1970 show that $70 \%$ of the structures were built before 1979, as compared to $68 \%$ of the structures 
for the City as a whole. 9 Bulldings as old as these need a considerable amount of attention, in terms of time and money, to be kept in proper repair.

A housing survey was undertaken to determine the condition of housing structares in the neighborhood. The survey methodology was identical to that used currently by the planning department of the City of Hartford on a neighborhood basis. Each structure was given a rating from A thru D. It is important to note that the survey was limited to exterior conditions only. No attempts were made to determine interior conditions. The following is an example of the survey that was conducted.

A Rating of:

A

B

$\mathrm{C}$

D
Given to a Structure That:

- is in fine shape with no apparent need of repair.

-needs some minor repair or maintenance and could be brought back to an A standard quickly and relatively cheaply. The house needs some paint, the drain spout is broken, etc.

- the building is need of major repair 1.e. the eves are rotting, the porch is sagging, the roof needs replacing, the foundation is cracked, etc.

-the building is dilapidated and could pose a danger to inhabitants. A building in this state might have been severely damaged by fire and there is question as to whether it can be salvaged.

In order to illustrate the relative condition of the neighborhood, the letter grade (A,B,C,D) given each struc- 
ture is assigned a numerical weight:

A is assigned the number 1

$B$ is assigned the number 2

$C$ is assigned the number 3

$D$ is assigned the number 4

From these numbers a Composite Blight Index is computed, which is the average condition of housing structures in the neighborhood. Here is an example of how the index is computed:

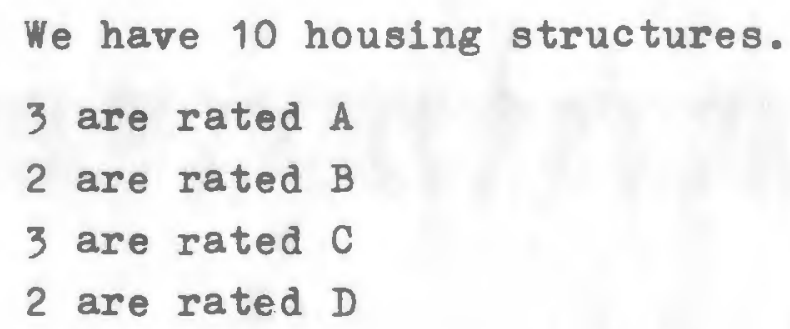

The actual Composite Blight Index for the study area is 2.5. The Table on the following page is a comparison with other areas of the City. 
Table 13: Composite Blight Index by Neighborhood.

Area

Parkville

Brookfield

South West

Blue Hills

Barry Square

Upper Albany

Asylum Hill

Park Street

South Green (study area)
Composite Blight Index (map of areas

on next page)
1.58

1.54

1.28

1.35

1.66

2.08

1.68

1.8

2.5

Source: survey completed in Mar. 1979; other Indexes from the Dept. of Community Planning \& Development, city of Hartford.

It can be seen in comparison with other neighborhoods in the City that the study area is in a seriously deteriorated condition.

Housing Units Lost

There has been a considerable amount of housing units lost in the study area. The historic building preservation project in the Congress Street area displaced lower and moderated income residents of 200 dwelling units. ${ }^{10}$ The area is currently being rehabilitated to provide housing for moderate and upper income groups. The growth of Hartford Hospital has led to the demolition of 37 housing struc- 



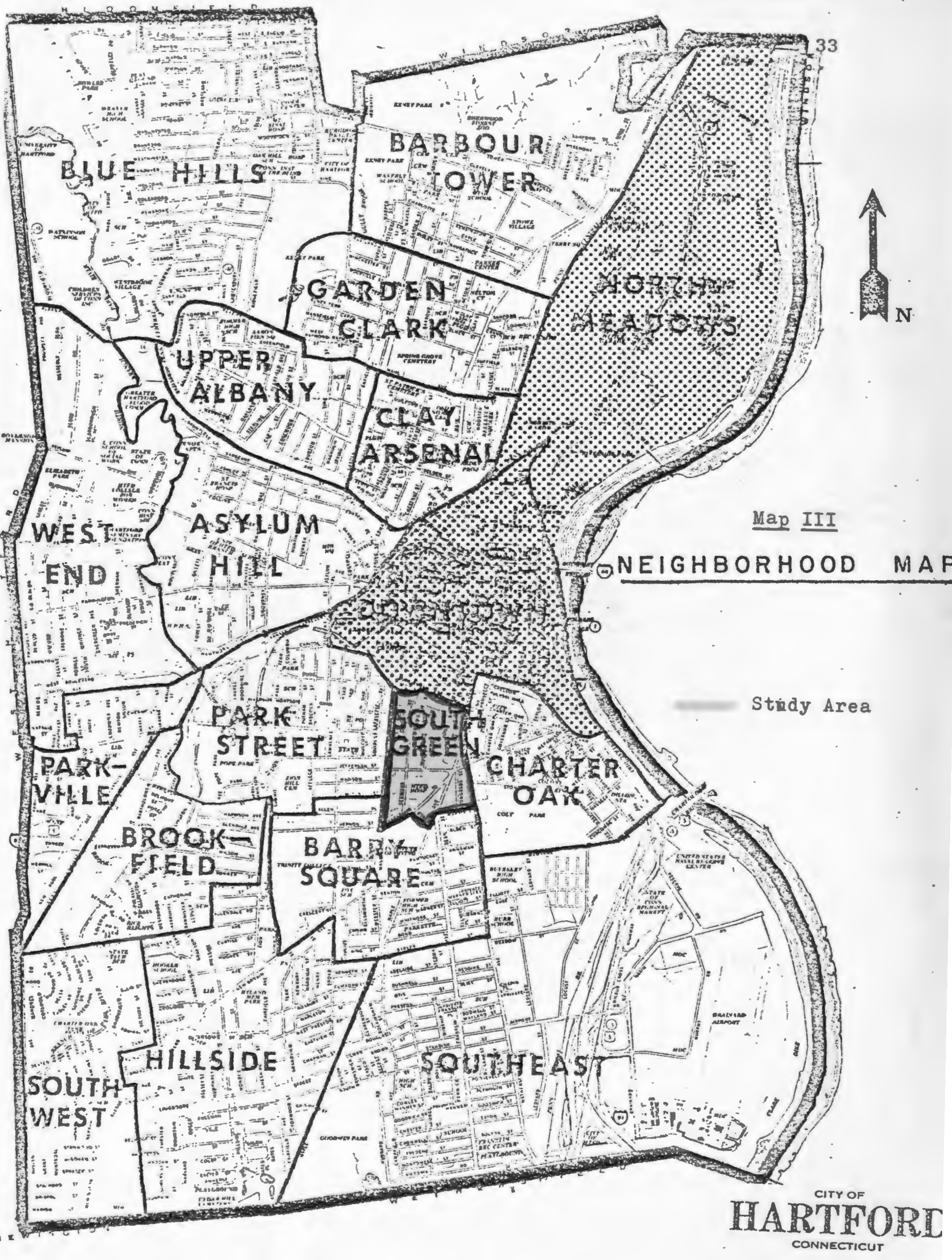


tures since 1950. ${ }^{11}$ A comparison cone by the City in February of 1979 shows that between 1965 and 1977 Buckingham Street lost 112 residential units, and Seymour Street had lost 57 residential units. ${ }^{12}$ The majority of these losses can be attributed to Hartford Hospital's expansion.

The neighborhood has gone through a number of changes, which include loss in housing units and nelghborhood deteroration. The socio-economic characteristics have changed within the population over time, transcending from a stable middle class neighborhood to one that has high concentrations of low-income residents.

The neighborhood is marked by high population turnover in relation to the City as a whole.

Table 14: Year Moved Into Unit.

Years

1968 thru Mar. 1970

1965 thru 1967

1960 thru 1964

1950 thru 1959

1949 or earlier
Hartford

$38.2 \%$

21.1

15.6

12.8

12.3
Study

Axea

$47.2 \%$

22.6

13.3

8.4

8.5

Source: U.S. Census for Hartford Connecticut.

These figures show that $83 \%$ of the population had not lived in their particular dwelling untt for more than 10 years, and $70 \%$ for not more than 5 years. The relatively 
high percentage (47.2) of those who had not lived there for more than two years indicates a highly transient population with probably a lesser amount of neighborhood identity.

\section{Contract Monthly Rent}

The contract monthly rent is the monthly rent price that landlord and tenant have agreed to, even if the furnishings, utilities or services are included.

Table 15: Median Contract Monthly Rent.

Area $1950 \quad 1960$ \%Change. 1970 \&Change

Hartford $\$ 38 \quad \$ 67 \quad+43 \% \quad \$ 109+38.5 \%$

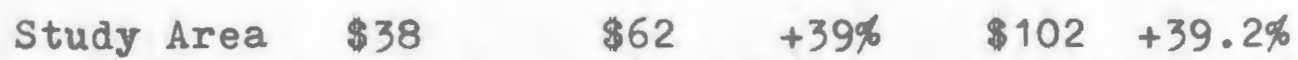

Source: U.S. Census for Hartford Connecticut.

Table 15 shows that rent costs in the neighborhood have not changed significantly with the remainder of the City. Given that the median income for the study area is lower $(\$ 9,108$ for the City and $\$ 6,750$ for the reighborhood, 1970), residents are forced to devote a greater percentage of their income toward pay1ng rent. ${ }^{13}$ This allows less money for other basic essentials such as food and clothing, not to mention health costs.

The City has been experiencing population loss from 1950 to 1970, resulting in a surplus of housing in the City. As can be seen in Table 16, there was a rise in the number of housing units that were for rent or sale. 
Table 16: Housing Units For Rent Or Sale.

\begin{tabular}{|c|c|c|c|}
\hline Area & 1950 & 1960 & 1970 \\
\hline City & $1.4 \%$ & $4.1 \%$ & $3.5 \%$ \\
\hline $\begin{array}{l}\text { Study } \\
\text { Area }\end{array}$ & $0.6 \%$ & $5.9 \%$ & $4 \%$ \\
\hline
\end{tabular}

Sources: U.S. Census for Hartford Connecticut, 1950, 1960 and 1970.

By looking at this table, we can see that the City's rate of excess housing appears to be declining. This is problably due to the amount of housing units that have been demolished throughout the City. A trend toward lower turnover in the housing stock can also indicate that the area is stabilizing.

The preceding data shows that residents around the Hartford Hospital area are at a relative disadvantage when compared to the remainder of the City. Officials have reported that there is a housing shortage for low-income families and individuals in the City. The Hospital's policy of demolishing existing housing structures for expansion is contibuting to this shortage. Since the study area is made up of predominately low-income groups, it is imperative that the existing housing be saved and maintained for their use.

Many of the residents who are displaced are at a disadvantage because of their low incomes, the housing shortage for these groups in the City, and the lack of trans- 
portation. Small businesses have been displaced by Hartford Hospital expansion. They operate on tight profit margins. Dislocation can have a disastrous effect on the viability of their operations. Chapter 3 describes what displacement is, the causes of displacement, and what it does to families, individuals and small businesses. 
Footnotes: Chapter 2 1970.

1U.S. Census Tracts for Hartford Connecticut, Table -4 ,

${ }^{2}$ Iarry Smith and Associates, Guide Report For Commercial And Industrial Renewal, Prepaed for the City of Hartford, Commission on the CIty Plan (New York, N.Y., 1964) p. 12.

3 Anthony Downs, "Urban Policy", in Setting National Priorities: The 1979 Budget, Joseph A. Pechman, editor, (Brookings Institute, Washington D.C., 1978) pp. 161-194.

${ }^{4}$ U.S. Census Tracts for Hartford Connecticut, Table H-2. ${ }^{5}$ Ibid., Table P-2.

${ }^{6}$ Interview with Edwin Hilliams, Housing Planner, Dept. of Community Planning and Developmate, Hartford Ct,, April 1979.

7 Lovett S. Gray, "Banks Snub Apattment houses", The Hartford Courant (Mar. 25, 1979) p. 1. records.

${ }^{8}$ Engineering Departmęnt, City of Hartford, demolition

${ }^{9}$ Department of Community Planning and Development, City of Hartford: Housing Policy and Anti-Displacement Action Progr教 (Mar. 1979) p. 14.

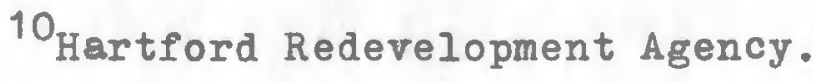

${ }^{11}$ Engineering Department, City of Hartfodd, demolition records.

${ }^{12}$ Department of Community Planning and Developement, 0p. Cit., p. 6.

${ }^{13}$ U.S. Census Tracts for Hartford Connecticut, Table P-1, 1970. 


\section{$\underline{\operatorname{Lin} P T E R} 3$}

RESIDENTIAL AND BUSINEUÜ DIOPLACENENT

\section{Introduction}

nisplacement is a term used to aescribe the forved removal of resjidert and businesses from where they ilvo, or where they gain their livelirood. Lisplacement can be attributed to four causes:

1. Urban renewal

2. In-migration of upper-income groups

3. Conversions, and

4. Deterioration and abandonment.

All of these types of displacement have occurred in the study area. The first part of this chapter will serve to explain what each of these forms of displacerent are, how they have occurred, and their potential effects on individuals and families. The second section is a presentation of interviews with residents and owners of amall businesses that have been displaced. and last, an interviaw with an individual businessman has been inclujed who has fears that he may be displaced someday.

Displacement $\underline{\text { By Urban Renewal }}$

Usually wher people think of urban renewal they mention government sponsored projects. In the past 20 to 30 years, the City of Hartford has torn down thousands of housing units to make way for projects like Constitution Plaza (situated where an Italian neighborhood once was) and for school construction. irom 1955 to 1979 a total $n f$ 
2,246 nousing units have been lost as a result of school construction alone. 2 The Charter Cak-south ireen project, part of which is contained in the study area. ras also resulted in housing, loss. ${ }^{3}$ The Eederal and itate governments have saused displacement by highway construction. Interstate 9.4 cuts directly through the center of the 0 ity. while Interstate 91 parallels the City's eastern boundary. Government are not the only unes who participat in urban renewal. Najor institutions, such as hospitals and insurance companies, private developers and other nongovernmental groups or individuals are sometimes responsible for losses in housing units and commercial strictures. Hartford hospital itself has been responsible for the loss of 37 housing structures as a result of expansion for parking lots and other uses. 4 In 1972, 15 housing units were demolished for the construction of a private medical complex adjacent to Hartford Hospital.

Displacement By In-migration of Upper-income Groups

This type of displacement is occurring as upperincome groups move into the city, occupying housirg structures that were once inhabited by low and moderate income groups. The costs incurred as a result of rehabilitation of these structures fffectively raises the rents for apartments. This usually precludes $10 \mathrm{~N}$ and moderate income groups from living there, causing their displacement. The renewed interest in city living by upper-income groups 
is a result of increased energy costs, the desire to be closer to their place of work and the cultural, social and other amenities that the city has to offer. A good supply of affordable housing exists for the conversion to upper-income housing. This of course, has put increased demand on the rental market, driving prices up beyond what low and moderate income groups can afford, resulting in less housing for these groups. 5

The previously mentioned "Congress Street" project displaced occupants of 200 low and moderate income houbing units and will be replaced by moderate and upper-income dwellings. City incentives to attract upper-income people back to the City such as tax deferrals and abatements, and rehabilitation loan and grant programs may have further increased displacment. 6

\section{Displacement By Conversions}

The City has been experiencing the conversions of residential units to non-residential units. Hartford Hospital, for example, serves to attract doctors and health related services to the neighborhood, who sometimes convert housing to other uses. This effectively displaces residents and diminishes the supply of housing available in the area and in the City. Another form of conversions is the demolishing of housing structures that contain two bedrooms or more and replacing them with one-bedroom units. This displaces families from areas 
where this type of conversion takes place.

Displacement By Deterioration ma ibardonment

The loss of housing stock through deterioration has been cited as the primary cause of displacement ir the iity.? The causes of deterioratior are numerous. Deterioration can occur where residents incomes are not sufficient to support the rents needed to properly maintain a housing structure. Banks in Hartford have put a freeze on mortgages to investor-owned apartment structures with five or more units. 8 Since the majority of the housing in Hartford is old, and since only $12 \%$ of the housing units are owner occupied, the cycle of disinvestment continues.

hbandonment is what George Sternlieb calls "the end product of all the urban ills of our modern society." 9 There are 23 vacant buildings in the study area, 17 of these are housing structures. Table 17 illustrates the extent that deterioration and abandonment has occurrei in the city.

The abandonment of a building is usually a reflection of the economic realities of owning property. An owner might find it cheaper to abandon a building if the costs of repair, taxes and insurance exceed the revenue beins generated. 10 In the meantime, because the owner has given up on the property, the building deteriorates.

There may be racial guestions associated with the ahandonment process. "Residential abandonent in terms 0 : 
environment appears to increase in areas of high 31 ack and Puerto Rican concentrations and thus becomes part of the dismal sosial and environmental conditicrs which are normally associated with these subpopulations." 11

Table 17: Privately Owned Vacant \& Abandoned structures In Hartford

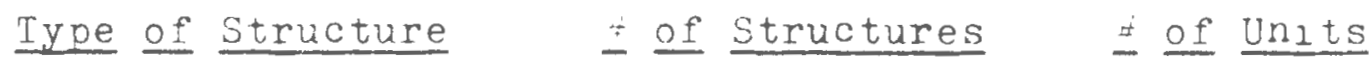

one family

two family

27

54

three family

32

93

apartments $1-\hbar$

53

273

apartments $7-10$

7

57

apartments $11^{1}-20$

18

259

apartments 21-100

6

190

roomirg houses

1

rotal

162

945

Source: Hartford Department of Economic Development.

The iity of Hartford which enforces code requirements or a complaint basis only, had displaced 33 households between 1975 and 1978, either because of fire damage or because the building was found to be unfit for human occupancy. 12 Neighborhoods that the city has found to be experiencing significant displacement show high mobility percentages in the elementary school populations that serve these areas. 
Losses In Housing Units

2isplacement has resuited in the reduction of housirg units avaiable to low and moderate incore individuals and families throughout the jity. There as a serious housing shortage for these groups. ms of January 1, 1979, 4.754 households were on the waiting list for the ection a Housing Program. ${ }^{12}$ Public housing through the Hartford Housing iuthority had a waiting list of 2,900 households in vetober of 1978 . The households on both lists qualified for low-income housing.

Lisplacement ind Its Effect On Feople

The issue of displacement goes beyond shifting low and moderate income households elsewhere, or the losses of affordable housing to these groups. Displacement car impose serious social, economic, psychological and physical changes that may have a negative effect on the wellbeing of affected families and individuals.

What are the costs and benefits that occur to the displaced" This section will outlirle some of the problems associated with displacement and the effects it can have on those who are forced to bear the resulting hurden.

People living in a given neighborhood will, in many cases, establish relationships with other persons, businesses and places. 14 These relationships mifht cunsist of having families or friends living nearov, knowirg the local merchants, or iust feeljng comfortable with the surrounding neigrbor- 
r.ood as a whole. To quote Anthony Downs, "these relationships represent the cumulative result of a large investment of time and enercy in personal activity." 15

The disruption of these established relationships by displacement can place a greater hardship on the elderly and low income groups because of fixed incomes and limited mobility. 16 As was shown previously, a large percentage of the Fartford Hospital area residents do not own automobiles. Displacement that serves to isolate these households from established relationships in their former neighborhood can leave negative social and emotional consequences.

One study $0:$ the effects of forced relocation in a working class community in the West ind Neighborhood of Boston has shown how strong, close-knit relationships can become. ${ }^{17}$ It was found that many of the residents who were dislocated attempted to reestablish or maintain continuity with the past. Rarely were their attempts successful.

The vosts And Benefits of Finding snother Place To Iive

The process of searching for a new house or apartment can require a considerable amount of time and money. An individual could be forced to take time off from work to look for an apartment or business location because of time constraints imposed by an eviction notice. Attempting to find suitable living ruarters at rents 
that were paid prior to displacement, has for the most part, been impossible. Ten follow-up studies of relocated persons in the United States ard vansda all report trat rent increased substantially. 18 since there is a housing shortage in Fartford, comoarable rente are difficult to locate. Most of the displacel people interviewed for tris study were forced to pay higher rents. In one case, the rent had almost doubled. 19

The ability to charge a given price for rent is a function of supply and demand in the housing market. To gaste one Hartford City Planner, "In any given neighborhood, if the situation is occurring where pressure is being placed on the housing stock from demands across tre economic board, then, unless there are certain kinds of controls or strategies that exist to counteract it, the prout with the most money who is demanding the same kind of hrisire is going to win."20 This means, of cource, that low-income groups in Hartford are forced to pay a larger percentage of their income toward housing that they had paid previnusly. This can be severe for the elderly and others who are living on fixed incomes.

Some relocation studies have found that people wiII try and relocate near their old neighborhood. 21 gor example, fifty-five percent of the families fom a Baltimore urban renewal project relocat ed within one-half mile of their previous homes. 22 cne exception was found ir Bostor's West ind whore those displaced were soread out all over 
the 3oston metropolitan area." The author suggests a number of reasons for these results. First of all, the population was almost entirely white, meaning that they probasy were not subject to exclusionary pressure, and two, the family incomes were relatively higher allowing docess to a larger market. In this study, of the seven people contarted who had been displace, six relncated within on. mile from their previous location. The other, a small businessman, had to go farther to find a suitable location for his store.

The degree to which displacement is harmful to an individual will vary depending on what the person experiences in the process. The ability to adapt to changes resulting from displacement, in terms of social and psychological impacts, appears to be correlated with row the individual or family has prepared for the cinange. 'A Sudden uprooting brought about by forced relocation has been shown to produce symotoms of grief in individuals; grief being the emotional conseguences of change in retatisn to the previously discussed close-knit networks, common in working class neighborhoods. 25 "While a majority of the working-class community may experience the sudden and drastic disruption of forced relocation as a crisis, it is likely to have auite different consequences for different individuals depending on their psychological, social and cultural readiness for meeting the challenge." 26 In fact, less than one third of the sample popilation in the Nest 
Lind study were satisfied and happy with the changes they experienced. Relocation then, can be seen as disrupting an established way of life for a great many people. These unwelcomed demands on residents within a given community have negative conseduences that in some cases go heyond the person's ability to cope.

The hardships associated with displacement can be seen in the following case illustrations. Three of these individuals were displaced by Hartford Hospital. The last interview is with a luncheonette owner who has a business located in a building owned by the Fospital. 


\section{Case Illustrations}

Th1s section will describe the events that led to the displacing of three people: Joe Bascetta, a shoe store owner; Matthew Tallow, a student who had lived at 98 Jefferson; and, Julius Schmidt, owner of Hartford Optical Company. 27

Each individual has a different way of expressing the discomfort and inconvenience they experienced as a result of displacement. The same basic questions were asked of each, so that a pattern could be developed. The purpose behind this section is to give the reader a better understanding of the serlous consequences of displacement and how it effects individuals. Hopefully, recommendations will be developed, sensitizing decision-makers to the overall impact of their actions.

Joe Bascetta, Owner of Pelican Footwear

When Joe was first informed that the Hospital owned the building his store was in, he decided to contact his new landlord. The first person he met was Howard Henrikson, caretaker of all of Hartford Hospital's properties. Joe was told that there would be nothing to worry about, things would remiain the same as before. When he met Mr. Henrikson for the second time, he was told not to make any long range plans, which Joe was told meant no longer than six months.

The building was purchased by the Hospital on Feb- 
ruary 1, 1978 and tenants recelved notices of eriction in April of 1978 .

Joe was served several eviction notices from the Sheriff's office because he could not leave within the specified period. He told Mr. Henrikson that he had nowhere else to go. "I was looking like crazy, I was checking. I called all of the real estate people. Nothing would turn up."

Mr Henrikson had one suggestion for a new location, a place not far from where Pelican Footwear was located. "It was a store that I could of had originally and I wouldn't take it for nothing. It's set back in, and besides, there was a tenant in there. I've known about that place for five years, it's not a good spot. Nobody ever made 1 t in there. This was a relocation plan? One place." The Hospital never offered Joe any money for relocation.

Within a couple of days after the Hospital acquired the building, Pelican Footwear window was smashed. Two days later the window was broken again. "I went up there and said, 'Look Mr. Henrikson, you told me everything was the same as it was before. And I assume you have insurance on it, like the last landlord, because whenever my windows got broken he replaced them you know."

"Well Joe, I'm sorry but we can't do anything about it. Now all of a sudden he's lying to me. He's telling me I'm going to have the same service, but he's not going to give it to me." 
Ater much bickering, the Hospital relented and said they wolid do the repair, cut trat Joe would have to get the estimates. He was incersed at this. te har nomerchardise in the store, the showcases were in shambles, and row he wolidd have to track down prices for the Hosputal. Ohe lowest estimate he could find was for $\$ 120 ;$ Mr. Herriksur offered him $\$ 100$.

There was another tenant above Joe's store who was receiving no cooperation from the Hospital as well. The tenant, Tony Dedristini, was not given any money to defray his relocation costs. Tony's age and physical condition comounded his problem. Joe talked to Mr. Henrikson about it. "Okay Mr. Kenrikson, Tony's not going to give you iny problem. The guy can't bend over to tie his shoe. He has to take sponge baths because he can't get in or out of the bathtub. I said, Just if you can do it, he has a stove up there, a refrigerator, a couple of bie neavy items. You can make it in two trips, it's only a few blocks away. You have alot of workmen, I said, maybe you can help him throwit in the truck, maybe one trip, maybe two. I'II move him in."

"Henrikson replied, 'Well Joe normally I would help him, but it's vacation time' and this and that. During that week there, I remember watching an office that was vacant and the workmen would be painting that place forever. I'd be standing out front not doing anythine, watching them, and they would be watching me. and he says they have no relp." 
Joe wanted time, not money. The move to Park Street did not end his troubles. His business is running in the red. "At this point, I got to be $\$ 13,000$ in the hole, maybe $\$ 14,000$. When I was on Jefferson Street, I didn't have any b111s like that. Because of the move, I had to get my showcases, I had to get this, I mean I was supposed to do things, take out loans. Okay, business is better, but I'm worse off here then I was there, because I'm now way in the hole .....whatever comes in goes immediately out." Rent is higher at the new location and the place is larger. "It's hard to calculate what I lost you know; because I'm five years over that building over there. I've had people from Springfield, Waterbury, New Haven. It's an odd little store and I had a following. The word got out that I was closed and had gone out of business. I keep hearing stories all the time. I don't want to believe them when I hear them."

Juliue Schmidt, Owner Of Hartford Optical Company

While listening to Mr. Schmidt, one can detect a sense of anger in his voice. A well spoken man, he talks freely of his encounters with urban renewal. Hartford Optical, which was started by his father 40 years ago, has been forced to relocate five times due to demolition. It seems now that Hartford Hospital's displacing of his store is the straw that broke the camel's back.

The eviction process went the same for Mr. Schmidt as 1t had for Joe Bascetta. Hartford Hospital did not offer 
any assistance in terms of time and money. The new location hasn't proven successful, though it is within a mile of the former site. In fact, Mr. Schmidt admits to doing only half the business he did previous to his move. "Up there I was the only place that could be seen as a store. There are other opticians there, but they're inside behind a window, whereas I had a store and could be seen. Plus the fact that I was closer to the doctors that once in awhile had an idea that they would send a patient, you know? Coming down here has just taken some of that away." The rent in his new place is about the same as the old store, but there is less space. Mr. Schmidt found his new location by walking around the neighborhood and talking with the merchants. He learned of a used clothing store that was run on a part-time basis. The owner was in his seventies and ready to retire. As Julias schmidt told of his exchange with the previous owner, one could sense the relief he felt in finding a new location through the tone in his voice and his mannerisms. As he explained: "These people are moving out, you can have that half (of the bullding). I said, 'Gee that's great, terrific, how much do you want?' He told me and I sald, 'Great', you know and I grabbed 1 t. Anything in a storm, you know what I mean? Because there was no place else around that was just as good. And I figure that eventually I could expand into this other place which would be terrific. I'd even make an animated sign with eyeglasses going across the front of it. I wanted to hitch a metal gate with a gold pair of glasses on top of it, you 
know. All different things that I had in my mind to do." He spent about ten days fixing up the new location. The cost of hiring someone to do the work was prohibitive, so he was forced to do the work himself. "I fixed this place up temporarily, with the idea that I was going to expand next door to where I am right now. But since I moved down here and seen what the location is like, I've made up my mind to close my doors. So I'll be out of business four months from now. August 1st I close. I've had all of 1t I want."

He's very bitter toward the Hospital now that he's learned that the building will be saved. Before, Schmidt was willing to accept the Hospital's intentions because he felt 1t was a necessary evil. He always felt that someday Hartford Hospital would want to expand and he was somewhat prepared mentally for 1t. "Now that the place is up almost a year, I would really like to go bask and sue them and say 'hey look, you didn't have to get me out of here, you should have known this before this', you know. Because it hurt my business, I had to quickly find a place to go."

"Here's a whole year gone by and I'm doing about half of what I did up there. Just the fact that your not in the phone book at your new address, people are going there and looking for you and all this kind of stuff. No, I don't raally know what the rules should be behind it. I only know that the laws are made so that their lawyers can step all over you and everything else. And there's almost no recourse when they do $1 t$, gou have no lease. They tell you 
'we're going to tear it down', you got to get out. They give you 30 or 60 days and you have to be out and that's it. The big problem starts with how do I go hire a lawyer to fight this."

Mr. Schmidt had gone through the process before when he had a store downtown. One lawyer advised him against fighting because the expense involved in bringing suit would be too costly. With the staff and resources of the Hospital, the case would have been kept in court for years. "This is the way it goes. Their the bigshots, you're the peons. We didn't get any place. I've batted my head against the wall with things like this and when it's all done with, they will beat your ears in, they will beat your ears in."

Matthew Tallow, Tenant of 98 Jefferson Street

Matt received a phone call from his old landlord informing him that 98 Jefferson had been sold to Hartford Hospital. He was given Mr. Henrikson's phone number. When Matt called, Henrikson told him that the Jefferson Street Medical Building, Inc. had bought the bullding, and that the tenants should be advised to start thinking in terms of moving. At this point, no decision had been made as to whether the building would be demollshed. The Jefferson Street Medical Building Corporation is the corporate arm of Hartford Hospital. 
Up to the time that the Hospltal owned the building, Matt had been living there for a year and a balf. He was not given any money for relocation, though he had tried in court to receive assistance. This was during his eviction proceedings.

"I asked the judge if Jefferson Medical would pay for moving my piano. That's when the judge grew incredibly angry and said that I wasn't trying to move in good faith. That was like a dam burst when I asked for money. After that they gave me seven days to move out." That was regardless of whether he had a place to go or not.

"I was just astounded that the system had so flagrantly violated my rights." Matt was interested in staying in the nelghborhood. He liked the area. After some searching, Matt was able to locate a place, around the corner from where he lived at 98 Jefferson. The rent at the new location was higher. At 98 Jefferson, he paid ninety dollars per month for four rooms with no heat included. At the new location he pays one hundred and thirty dollars for two rooms with heat.

Matt is concerned about the neighborhood and how 1t's being affected by Hoopitel policies. "It's not only that they may pick up this bullding or that bullding, you know? It's even bigger then that. Just their presence there and the fact that no one knows what they're going to do causes speculation, and causes landlords to not put money into their properties, just to wait because they think it will happen any day. I think that's the main problem. If we 
could pet some means of assuring that there are certain areas that they will never go to, then possibly some of that effect will be reduced."

Matt feels that Jefferson street Medical vorporatior. should not be involved in caring for the housing units Hartford Hospital owns. Rather a professional management company should be retained so that tenants will know where to turn to for help when they need it. He feels that Jefferson Medical is just too big to provide the type of communication necessary to maintain the Hospital's properties. "Jefferson Medical has a tendancy to harass and to disregard the tenants. I can't see the need for them to do it." Matt would also like to see the housing units being rehabilitated at the corner of Seymour and Jefferson streets made available to everyone, and not just Hospital employees.

The next interview provide the reader with an example of how the fear of displacement has affected an individual businessman in the Hartford Hospital area.

Interview with Mr. of Mr. $\mathrm{K}^{\prime} \mathrm{s}$ Luncheonette, 104 Jefferson St. Mr $K$ operates a luncheonette on Jefferson Street in a building owned by Fartford Fospital. Mr. K has increasingly become involved with residents in the area to get the Hospital to cooperate with the neighborhood. He's so concerned about the future of his business and the neighborhood that he allowed a press conference to be held in his res- 
taurant. The conference was used to inform the general public of the neighborhoods fight to stop Hartford Hospital expansion.

He has been at his present location for two years. This leaves Mr. K with eight years to go on a ten year lease. Mr. K's first run-in with the hospital was about parking. The Hospital informed him that he could not park in Pront of his business anymore. They sald that they intended to do some landscaping and planting in front of his business. He had no problem with the idea as long as they provided him with a place to park. They said they would not.

As customers watched and listened, Mr. Henrikson told Mr. K that if he didn't move his car it would be towed. Incensed at the way he was being treated by his landlord, Mr. K wrote a letter to Hartford Mayor George Athanson requesting that something be done.

To quote Mr. $R$, "You know what it is, 1t's another way of raising your rent, you know. If you don't park it there, then you have to go in the garage and pay them another 30 , 40 or 50 dollars, which I think I'm paying too much (rent for the restaurant) anyhow right here now." The Hospital operates a parking garage across the street from Mr. K's business. The garage is located in an area that once was housing.

The Hospital was angry when they heard that Mr. $K$ had contacted the City. A Hospital employee came into the restaurant and told $M r . K$ that he couldn't park his car in front of his business. In Mr. K's words, "The next day he 
comes in and says 'you can't park your car there, it's a Eire hazard' and everything. Well, I said, I'm going to park the car there as long as I'm paying rent here. I said, lonk, I'm paying alot of rent here, I'm not being treated like I was paying rent, like he was doing me a favor. 'hell I don't give a god damn', he says, 'we don't want this god damn building, we're going to keep it because you have a long lease. The minute your lease is gone', he says, 'we are going to tear it down'. He says, 'we have time, we're going to wait till you get out then we're going to toar it down'.....that's what he told me." After being pressured from the uity, Mr. Henrikson told Mr. K that parking would be provided.

According to $\mathrm{Mr}$. K, cooperation from the Hospital is non-existent. When they bought the building, tenants were told roof repairs would be made. The roofers did come, installing scaffolding in front of Mr. K's business, making it difficult for customers to enter the restaurant. They threw debris down from the top, risking injury to customers and pedestrians below.

Mr. K notified officials at the Hospital about the situation. "I waited and waited and nothing happened. "I called City Hall and said 'this is a hazard'... they came and put a stop to it."

In october of 1979 , the Hospital started repairs on the building's furnace. It was 27 degrees outside, according to Mr. $k$, and there was not heat in the restaurant. He informed the Hospital about the problem. "Hey, there is no 
heat and it's cold out. 'Well', he says, just sarcastic like that, 'they gay it's going to warm up.' Well that doesn't do me any good. I have a business to run. Do you have a heating unit? If you don't have one, I'm going to buy one and charge you. In the afternoon they brought a heater. It's silly things like that, you know, that makes you feel that you are not welcome in this place."

Mr.K is worried about his future here. He doesn't know what the Hospital's next move will be. They have said that there are no plans. To quote Mr. K, "I have here $\$ 5,000, \$ 10,000$ or $\$ 20,000$ here. I know what I'm going to do. One hundred and sixty million dollars and you don't have any plans? You don't know? How in the hell are they growing? You don't have any plans, you don't grow!" Hospital officials have said that his building will not be torn down, but have refused to put anything in writing. "How in the heck for all these years have they been getting away with these things, tearing down buildings there (pointing to the site where housing once was), taxes don't go to City Hall. What they did, they turned around and raised my taxes and someone elses taxes. How the heck could you close you eyes for so many years? You don't have to be a genius, we told City Hall, if they tear down 10 or 20 bulldings that there are no taxes for you. Who's paying those taxes? I come here, I hardly make a living. All of a sudden I get taxed so much... I don't send... a pink slip comes in." 


\section{Displacement In the Study Area}

The problems faced by individuals in the case 11lustrations represents some of the effects that take place as a result of displacement. They were all forced to pay h1gher rents at their new locations. Th1s is in agreement with most studies on displacement, that relocation usually means paying more rent than in the previous location. ${ }^{28}$

The second common factor among those interviewed, was that they tried to relocate in the area from which they were displaced. This was also found to be the case in a relocation study of 41 major U.S. Cities. 29 Joe Bascetta and Julius Schmidt whed to wetn in the area because they earned their livlihood there. Matt Tallow liked his nelghborhood. He was fortumate to find a location near his old apartment. The rent is higher and there is less room.

Operating a small business is a delicate task that depends on low profit margins to compete, and a healthy cash flow to keep the business well stocked with goods. Dislocation for these businessmen meant losses in customers and working capital. It also involves moving expenses, which include renovating the new location. These expenses oan be overwhelming, as was the case with Joe Bascetta and Julius Schmidt.

Dislocation is expensive and time consuming. In all cases, the Hospital did not offer tenants relocation funds, or provide worker or transportation that would have facilitated the moving process. The Hospital was not concerned with what would happen to the tenants as a consequence of their 
actions.

The next chapter discusses hospltal planning and control as it takes place at the federal, state and local levels of government. Th1s chapter is important because it defines the various attempts that have been made to regulate hospital expansion and shows the framework within which declsions for Hartford Hospital must occur. 
Footnotes: Chapter 3

${ }^{1}$ Department of Community Planning and Development, City of Hartford: Housing Policy and Ant1-Displacement Action program (Mar. 1979)

2Ib1d., p. 4

${ }^{3}$ Hextord Redevelopment Agency.

${ }^{4}$ Engineering Department, City of Hartford, demolition records.

${ }^{5}$ Department of Community Pranning and Development, $0 p$. Cit., p. 8 .

${ }^{6}$ Ibid., p. 10.

7 Ib1d., p. 13

8stephanie Sevick, "Deterioration Seen Displacing Poor" The Hartford Courant, (April 1, 1979) p. 39.

${ }^{9}$ George Sternlieb and Robert W. Burchell, Residential Abandonment: The Tenement Iandlord Revisited (Center for Urban Policy Research, Rutgers University, New Brunswick, N.J., 1973) p. xil.

${ }^{10}$ Ibid., p. xvi11.

${ }^{11}$ Ibid., p. xv11.

${ }^{12}$ Department of Community Planning and Development, $\mathrm{p}$. Cit., p. 17.

${ }^{13}$ Ibid., p. 16.

${ }^{14}$ Anthony Downs, Urban Problems and Prospects, Chapter 8, "Losses Imposed on Urban Households by Uncompensated Highway and Renewal Costs" (Markham Publishing Co., Chicago, 1971) p. 192.

${ }^{15}$ Ibid., p. 194

${ }^{15}$ Herbert Gans, People and Plans: Essays on Urban Problems and Solutions (Bagic Books Inc., New York, 1968) p. 217. 
17 Marc Fried, "Functions of the Working Class Communlty on Modern Urban Society: Ifwplieations for Forced Relocation". The American Institute of Planners Journal (Vol. 33, No. 2

18 Chester Hartman, "The Politics of Housing: Displaced Persons", Society Magazine (July/Aug., 1972) p. 61.

${ }^{19}$ Interview with Joe Bascetta, Owner of Pelican Footwear, April 1979.

${ }^{20}$ Interview with Bawin Williams, Department of Community Planning and Detelopment, Hartford, Epril 1979.

${ }^{21}$ Hartman, Op. Cit. p. 60.

${ }^{22}$ Chester Hartman, "The Housing of Relocated Families" in Urban Renoral: The Record and the Controversy, James Q. wilson, editor (M.I.T. Press, Cambridge 1966) p. 298.

23 Ibid., p. 298.

${ }^{24}$ Marc Fried, Op. Cit. p. 90.

${ }^{25}$ Ibid., p. 93.

${ }^{26}$ Ibid., p. 93.

27 Interviews were condusted in April of 1979.

${ }^{28}$ Chester Hattman, Society Magazine, Op. Cit. p. 61.

${ }^{29}$ Chester Hartien, Urban Fenewal: The Record and the Controversy, Op. Cit. p. 298. 


\section{CHAPTER 4}

\section{HOSPITAL PLANNING}

\section{AT THE}

\section{PEDERAL, STATE AND LOCAI LEVEL}

I. Hospital Planning at the Federal Level

A. The Hospital Survey and Construation Act of 1946

During the Depression and World War II, few hospitals were being bullt throughout the United States. At that time, many of the existing facilities were fast becoming obsolete and there tended to be shortages of beds between states, as well as shortages in rural areas within individual states. ${ }^{1}$ To identify and meet some of these shortcomings, the U.S. Congress implemented the Hospital Survey and Construction Act of 1946, which came to be known as the Hill-Burton Program. The major objectives of the program were to: gather an inventory of existing health facilitses, to determine if there was a need for more hospitals, and to develop a program to insure that the necessary facilities and services were developed. The Act called for the construction of both public and non'profit hospttals. The program was set up as federal-state partnership, with the federal government providing grants to the states for surveying health care needs and then alloting money for construction of facilities. The state plans were subject to federal approval.

There has been some disagreement in defining what is meant by adequate health care. Between 1946 and 1965 standards were set according to a ration of beds to the population. ${ }^{2}$ This was criticized by some because the need for hospltalization 
could vary from region to region, even though population was the same size within each separate service area. This could have resulted in overcrowing in some hospitals, while other facilities would be underutilized. In ignb, a new formula was developed to overcome this deficiency. I'rree factors were used: 1) five year population orojections, 2) current utilization rates, which was the number of bed days used by the population, and 3) an occupancy factor, which was the average percentage of beds maintained for patient care that were filled. 3

Priorities for providing hospital beds in rural areas were high, with the hopes that new facilities would attract more physicians to these rural areas. This priority was challenged by urban hospitals and organized nealth groups. - 1970 amendment to the kct shifted the priority toward poorer areas where funds for modernizatjon of existing facilities would go first. ${ }^{4}$ The amendment not only alloted aid to urban areas, it also marked a move from new construction to utilization of existing facilities. States were given a considerable amount of power to implement their plans because of Hill-Burton construction and renovation grants. 5 states could attach certain requirements to hospital requests before they would consider their application for funding. One federal regulaton required that hospitals who received grants provide anywhere from 3 to $5 \%$ free care.

On July 1970, Congress authorized guarantees with interest subsidies for loans arranged by private, non-pro- 
fit health facilities. 6 This amendment made $\$ 500$ million avaliable per year for three years in loans and loan guarantees.

B. The National Health Planning and Resources Development Act of 1974

As health care costs were skyrocketing, Congress became concerned with the performance and efficiency of the health care system, 7 The massive infusion of federal dollars through the H1Il-Burton Progran, Medicare and Medicald led to inflation of health care costs. The National Health Planning and Resources Development Act of 1974 was an attempt to approach health planning in a rational and comprehensive manner. 8 Congress found that the lack of uniformiy effective methods of delivering health care, maldistribution of health care facilities and manpower, and the increasing cost of health care, led to an overlapping of health service facilities and inflation. The 1974 Act called for more coordination or consolidation of institutional health services, and for sharing of support services among health service institutions. The Act also provides for the establishment of Health Systems Agencies. These agencies operate on a regional basis to coordinate health related activities. Generally, the HSA serves an area of over 500,000 people and not more than 3 million people. Governors of each state may request an exception to this rule, with final approval decided by the secretary of Health, 
Education and Welfare. There are presently 5 HSA's in Connectiout with approximately 200 distributed throughout the United States. 9

The HSA's purpose is to collect and analyze health data, determine the health of residents and their needs, as well as determine the status of the health care delivery system within their boundaries. This is done in terms of services offered, manpower needs and facilities requirements. These HSA'a are funded by the federal government.

In aneffort to meet the health care needs of all those concerned, Congress has included within the Act a multilevel participation process for iforming health care policy. Within the Health Systems Agency is a governing body of no less than 10 and no more than 30 members, who are responsible for the establishment of a health systems plan and an annual implementation plan. ${ }^{10,11}$ A majority but not more than $60 \%$ of the body must be consumers and not providers of health care, representing the economic, social, linguistic, and racial population of the area. The remainder of the members are providers of health services 1.e., doctors, dentists, hospital administrators, health care insurers, and other allied health providers. All members of the governing body must reside within the health care service area.

The 1974 Act also includes a provision for the designation of a state health planning and development agency. One of the duties of the state health planning agency is to prepare a preliminary state health plan, made up of a 
group of health service plans. Any plan that is completed is subject to approval or disapproval by the statewide Coordination Council. 12 Another important function of the state agency is to administer a Certificate of Need Program (CON). The purpose of the CON is to provide for review and determination of need for any proposed new service, facility, or organization.

Another function of the 1974 Act that was included in the text of the legislation but as of yet has not been implemented, is the "appropriateness review" clause. 13 This clause provides for the perlodic review (not less than every flve years) of all institutional health services being offered in the state by the HSA and the state health planning agencies. Its purpose would be to determine the appropriateness of existing services. All findings would then be released to the public.

II. Health Planning and Control in the State of Connecticut The State health planning process 1s'an extension of of the National Health Planning and Resources Development Act of 1974. In the state of Connecticut, the Health Systems Agency (HSA) is the basic building block in the health planning process. 14 The five HSA's in this State can only make recommendations and do not have any decision making power. The only entity empowered to make decisions is the Commission on Hospitals and Health Care as designated by the Connecticut Legislature. 15 
The vommission consists of seventeen persons who are appointed. Twelve of these members are appointed by the Governor, as follows: a hospital administrator, firom a list of those submitted by the connecticut Hospital issociation; a nursing home administrator, from a list of names submitted by the Connecticut nursing home industry; a licensed physician engaged in a non-hospital, clinically based practice, from a list submitted by the connecticut State iledical Society; a registered nurse; one person active in a hospital service corporation; and seven public members in which urban and rural geographical considerations must be taken into account. One public member is appointed by the president pro Tempore of the Senate, and another by the speaker of the House of kepresentatives. The vommissioners of the Wental Health, Insurance, and Fealth Services are also included on the vommission. The bublic members cannot be affiliated with the health industry in any way. Commission members serve for a period of tive years. The Governor appoints a chairperson and vice chairperson of the commission from among the public members. The vommission's general duties are to review the health care delivery system in the State, recommend improvements in the delivery system. They are also required to report to the Governor and Legislature once a year. Their objectives are to promote efficiency, orevent duplication of services and facilitjes, lower hedlth costs and enerally improve health cars throughout the state. 
The vomission is also empowered to reguiate rates or charges of any health care facility or institution that has requested an increase. They are required to hold a public hearing if the commission has judped an increase to be excessive.

Tne following four approval/disapproval cowers invested in the Uommission on Hospitals and Hedth vare are extremely important within the context of this paper hecause they effect the ability of a health facility to expand.

Section 19-731. Approval process for the introduction of additional functions or services; increases in staffing.

If a hospital plans to introduce additional services and functions, or increase staff higher than by a percentage set by the Commission, it must submit to the vommission a request to do so. The purpose of the review process is to determine whether tine request for extra staff or additions in service of functions is justified. The lommission can grant or deny such a request within 90 days of submission. approval is automatic if the Commission fails to act within 90 days.

Another important function that the vommission has is the abjlity to approve or disapprove capital expenditures of healtr care facilities. There are two types of requests: those that involve capital expenditures of one hundrei thousand dollars or more (Section 19-73m), and those capital expenditures that are in exoess of fifty thousand dol- 
lars but less than one hundred thousand dollars Section 1973n). Each one will be dealt with separately.

Section 19-73m. Requests for approval of capital expenditures of one hundred thousand dollars or more. Any hospital expenditure that amounts to one hundred thousand dollars or more, including rental of equipment or facilities, must go through a review by the Commission. Hartford Hospital would have to submit all data, information and plans, ninety days before they intend to initiate the expenditure. The Commission is then required to give formal notice of a public hearing on the matter.

Request for approval by the hospital must also be sent to the Health Systems Agency who will review the proposal and make recommendations to the Commission. ${ }^{16}$ The Commission has the power to either approve, modify, or deny the request. The Commission looks to see if the request will effect the operating costs of the hospital and whether there is a regional need for such a capital program.

One example of the Commission's authority involves a hospital affiliated with Yale Medical School. The hospital had applied through the Certficate of Need process (CON) for permission to begin major renovations. The Comnission, after reviewing the plans and determining the need, ruled that the hospital would have to cut back on the number of beds. As a result, Yale is now suing the Commisssion. ${ }^{17}$ 
Section $19-73 n$. Recuest relative to lesser capital expenditures.

my capital expenditure by a health facility that is in excess of fifty thousand dollars, but less than onehundred thousand dollars, which includes leasing of emipmert or facilities, is required to flle for a voN, thirty, days prior to the initiation date o: the expenditure. It' reasonable, they will hold a public hearing, giving at least seven days notice. If after the hearing, the commission decides that the need has not been justified, they wili delay the project for six months at which time the report may be resubmitted for reconsideration. If the lommission fails to act within thirty days of resubmission, it shall be deemed approved. The health Systems Agencies usually wave their right to review requests under $\$ 100,000$.

Section 19-i3t. Taking of land to enlarge hospitals. A non-profit hospital, licensed by the State, that provides services to the public, and wishes to expand but carnot get tit]e to land and buildings required for their expansion, can apply to superior court to invoke eminent domain procedures, provided the Commission has approved such a request. If the jommission has approved such a raguest, the court will appoint a committee of three disinterestei persons who will report to the judge findinge pertinent to tre taking of the land. If the court committee rules in favor of the taking and the judge accepts such a report, eminent domain procerdings can take clace. 
As is required by law under eminent domain proceedings, those affected by such a taking must be justly compensated.

III. Hospital Planning Controls in the City of Hartford The nelghborhood has been applying pressure of officials in Hartford to respond to the issues involving Hartford Hospital's expansion. As a result, City planning staff have been assigned to work with nelghborhood residents and business people to develop a liason between the nelghborhood, hospital officials and the City.

Presently, the land ourrounding the Hospital is zoned for commercial/residential use. This zoning does not offer any control over the Hospital's expansion. The City has been looking toward an ordinance in San Francisco that requires hospitals and other institutions to develop a master plan. The San Francisco ordinancd comes under that city's conditional use code (section 303), which was amended to establish requirements for institutional master plans. (Section 304.5)

Section 303 Conditional Uses (San Francisco) An application for a conditional use by an institution is needed to begin the approval process. After a hearing is held, the city planning commission may approve the application providing it satisifies the following critieria: 1) the proposed use is necessary or desirable for, and compatible with the neighborhood or the community, 
2) that the use as proposed will not be detrimental to the health, safety, convenlence, and general welfare of persons residing or working in the vicinity. This requirement may include considerations of traffic, noise, parking, and accessibility, and 3 ) that the use will not adversiy affect the city's master plan.

Any decision by the city planning commission can be appealed to the Board of Supervisors. The city planning commission, or the Board of Supervisors, on appeal, can prescribe additional conditions if they feel that it is necessary to meet the objectives of the conditional use code.

Section 304.5 Institutional Master Plan (San Francisco)

The purpose of the Institutional Master Plan is to: 1) provide notice to the planning commission, community, neighborhood, organizations, and others as to the plans of the institution, so that those informed are given an opportunity for early and meaningful involvement in such plans, 2) enable the institution to modify it's plans in response to public hearings, prior to the institution's completing more detailed plans, and 3) provide the city planning commission, community, neighborhood organizations and others with information that may help guide their decisions with regard to use of and investment in land, and to prevent duplication by other institutions. After an institution adopts a master plan it is 
required under the ordinance to file a report with the city planning department every two years, describing the current status of that plan. It's also required that the plan be avallable to the general public.

The format and content of the master plan has to include a description of what the institution does, its history of growth, physical changes in the neighborhood as a result of 1 ts growth, the services it provides, its service population and a list of the properties that the institution owns throughout the city. The Master plan has to also lclude land use patterns, parking, traffic patterns and physical locations of buildings.

The development plans must reflect a future period of tien years, along with physical changes that will be needed to achieve the plans. In addition, the plan has to conform to the city's master plan, as well as contain analyses of the following: it's effect on the neighborhood in terms of affecting dwelling units; on relocation of residential, commercial and industrial tenants; and, impacts on traffic, circulation and parking. They also must provide alternatives which might avold or lessen impacts on the ourrounding neighborhood.

A public hearing is required for any proposed revision to the established master plan. There is also a requirenent that the plan be submitted by the city planning department to the San Francisco Comprehensive Health Planning Council, which follows guidelines set within Public Law 93-641, which 
is the National Health Planning and Resources Development Act of 1974. The city planning department will not authorize any building permit until the institutional master plan has been filed.

As this chapter shows, attempts to control hospital expansion has occured at all levels of government. These controls are only as effective as the letter and intent of the law are followed. It appears that many of the regulatory mechanisms are tied directly into the political process, in that the Governor and legislative leaders in the State appoint hospital Commission members. At the local level, the Zoning or Planning board may also base decisions on political considerations. Regardless of all of these circumstances, the hospital master plan is a useful concept when implemented because it allows the public to anticipate and monitor hospital expansion. 
Pootnotes: Chapter 4

1 Judith $\mathrm{R}$. Lave and Lester B. Lave, The Hospital Construction Act: An Evaluation of the Hill-Burton Program, 19481973 (Amerd tan Enterprise Institute for Public Policy Research, Washington D.C., 1974) p. 3.

${ }^{2}$ Ibid., p. 9.

${ }^{3}$ Ibid., p. 9 .

${ }^{4}$ Ibid., p. 10

${ }^{5}$ Ibid., p. 23 .

${ }^{6}$ American Hospital Association, Major Federal Aid Programs for Hospitals (American Hospital Assoc., Chicago, 1970) p. 2.

7 El1 Ginzberg, The Iimits of Health Reform (Basic Books, Inc., New York, 1977 ) p. 42 .

893 rd Congress, 2nd Session, House of Representatives, Conference Report No. 93-1640; National Health Planning and Resources Development het of 1974 (Dec. 19, 1974)

${ }^{9}$ Interview with Don Ingalls, Health Planning Staff, State of Connecticut, April, 1979.

${ }^{10}$ Public Law 93-641, Section 1512, Part 3, of the U.S. Statutes.

${ }^{11}$ They may exceed 30 members if they establish another unit called the "executive committee". Also, the annual implementation plan (AIP) is the process used to acheive the goals of the health systems plan.

${ }^{12}$ In Cennestout it is known as the Commission on Hospitals and Health Care.

${ }^{13}$ Don Ingalls, Op. Cit.

14 Ib1d.,

${ }^{15}$ General Statutes of Connecticut, Title 19, Section 19-73a. 
Tion Irâtalls, Op. Ojt.

${ }^{17}$ Ibid. 


\section{CHAPTER 5}

CONCLUSIONS AND RECOMMENDATIONS

Hartford Hospital continues to implement policies that force residents from their homes, adding to Hartford's already severe housing shortage. Government officials in Washington are attempting to end wasteful spending by the Country's health institutions. In fact, the Carter Administration is making hopital costs one of it's prime targets in the fight to hold down inflation. ${ }^{1}$ The government is concerned because American taxpayers are paying fiftyfive percent of costs incurred in U.S. hoopitals, through public insurance programs, Medicare and Medicald. With these tax dollars, plus private health insurance, like Blue Cross, Americans cover ninety percent of their hospitilization costs. ${ }^{2}$ Since hospitals are operating on a somewhat guaranteed supply of money, there are no incentives to cut back unneeded service delivery. The National Health Planning and Resources Development Act of 1974, designed to hold back hospital construction and unnecessary duplication of equipment and services, is failing. ${ }^{3}$

The Hill-Burton Act which was passed to encourage more hospital beds has gone beyond its goal; there is now an excess amount of hospital beds in this country. ${ }^{4}$ There is a decline in the number of patients entering hospitals in the Hartford region, and when they do enter they usually do not stay as long. ${ }^{5}$ Maintaining unused hospital beds is an expensive proposition. For this reason, hospital administrators are trying to market their 
hospitals to attract doctors. Doctars bring in patients. In a market where demand for health services is declining due to more efficient medicine, the need to lure qualified and respected staff is imperative. Hospitals provide incentives. Mr. Somoza has mentioned that free parking is one of the amenities that Hartford Hospital is using to attract staff. 6 This policy has had obvious negative effects on housing in the area, as well as producing undesirable types of land-use for the nelghborhood and the city.

Though Hartford Hospital and other medical institutions in the Hartford area are competing for patients, they have recognized the need to converge and avold costly duplication. A consortium of nine health institutions was developed so that more cooperation could be achieved. The consortium is composed of Hartford Hospltal, St. Francis Hospital, Mount Sinal Hospital, New Britain Hospital, Manchester Hospital, the University of Connectiaut Health Center, the Newington Children's Hospital, the Institute of Living, and the Veteran's Hospital in Newington. 7

The Executive Director of the Oonsortium has recently resigned because member institutions are not willing to develop increased interdependence with each other, such as shared administrative services and joint land development. To quote John M. Danielson, the resigning Executive Director of the Consortium, "We've reached a plateau. The consortium is unique in that we have developed exclusively medical cooperation, like an integrated nervous system instead of a muscle system or a whole body." Mr. Danielson also added, 
"I've taken this group in Hartford about as far as I can. Detroit is 10 years ahead in that the hospitals are actually merging and the corporate and political leaderahip is fully committed to integration." 8

Recommendation \#1

The "appropriateness review" clause of the 1974 Health Act has not been implemented. It is imperative that hospitals undergo a review process to determine whether existing services are still needed. It is recommended that the State take it upon itself to develop controls of its own that will enable hospital growth to be regulated. This could be achieved by adapting an appropriateness review clause to the existing legislation. It is also recommended that Section 19-73n, "requests relative to lesser capital expenditures" which is contained in the Connecticut Statutes, Title 19, Chapter 334 be strictly enforced. This section pertains to expenditures between fifty thousand dollars and one hundred thousand dollars. Presently the Health Systems Agencies waive their option to require a Certificate of Need statement. The most damaging part of Hartford Hospital's expansion has been the incremental but devastating process of buying up one or two dwellings at a time.

This process has had a substantial impact on the surrounding neighborhood. The Health System Agencies create plans which are then combined to formulate a state health plan. It is important to realize that the sum of their 
plans can have a sizeable impact on the entire planning provess.

To many of the resicents attending, the March lyth meeting between Hartfond Hospital officials and the neighborhood was a failure. First of all, the oress was not allowed in on the discusion: seconaly, no commitments were made by Hospitil officials with regards to nejghborhood involvement in the planirg process. The only promises made to the residerts were: 1) to notify them in advarce of any physical changes that were planned for residertial property owned or acquired by the hospital, and 2) that the' agreed to paricipate in a neighborhood liaison committet at the neighborhood's suggestion.

The residents, having taken an active role in saving their neighborhood, do not want to be informed of any impending plans, rather they want to be involved in the planning process. is a result of neighborhond pressure, City officials have been working to smooth differences between residents and the Hospital.

Councilwoman Mildred S. Torres, chairwoman of the sducation, Public Safety and Zoning Committee met on April 2, 1979, with members of the Jefferson-HudsonSeymour-ketreat Neighbors, and Paul Somoza, Direotor of Planning for the Fospital. The residents expressed their concern for the future of the neighborhood. They felt that because the Hospital has exerted sirch a great influence on their neighborhood's develupment, residents in the area 
should be involved in the planning process. volncilw man Iorres suggested to Mr. Somoza that he put his oromise that the Hospital has no future plans for expansion in writing. Mr. Somoza felt it was not necessary.

In a letter sent on April 5 th by inuncilmember Torres, to the Mayor and other Counoilmembers, it was noted that the neighborhood liaison group would rot have any input. into the planning process. They would only be allowed to review prepared plans presented to them by the tospital. The Hartiord planning staff has been assigned to the problem and are looking at ways to control or modify Hartford Hospital's expansion. One example is San Franrisco's institutional master plan ordinance. Jon Voleman, Harteord's Director of lommunity Planning and Development nas stated that he has a good faith understanding with the Hospital trat no more demolition or expansion will take place unti? the Jiaison committee is established. 9 at a meeting with hospital officials, Coleman had asked that they plan iuture development on Iand that is already vacant. It was suggested that the existing parking lots could be user for additjonal bulldings, and that parking could be located under office space. City planners are concerned with the kosnital's policy of demolishing residential struatures for the creation of parking lots. These actions have negitively impacted the City's already depleted tax base. kccording to 19?'? assessor records, Hartford Hospital owns $\$ 30,864,840$ worth of tax exempt property. 10 This results in a $\$ 2,800,058$ loss in taxable property income to the lity. 
Recommendation \#2

The City of Hartford is slowly losing taxable land because of expansion of non-profit institutions. Approximately sixty percent of Hartford's land area is non-taxable. The slow, but steady expansion of Hartford Hospital creates a significant and permanent tax loss. This expansion, added to the seemingly minute expansion of other non-profit institutions has a sizeable impact on the City's tax base. This expansion affects the City's ability to deliver services, requiring more taxes on the surrounding properties.

It is recommended that all major non-profit institutions be required to submit master plans, similar to that used in San Francisco. Through careful examination, a workable solution could be reached that would not prove to be burdensome to smaller non-profit institutions such as churches. A plan of this nature would put the City in a better position to monitor growth of non-profit institutions throughout the City. Presently, no effective methods exist to accomplish this task.

The next step in negotiations with the Hospital will be through the neighborhood liaison committee. Residents in the area want to plan with the Hospital while Hartford Hospital officials want residents to participate after plans have been developed.

Can we call this true citizen partictpation? To answer this question, we must define what is meant by citi- 
zen participation. One author las defined aitizen rarticipation to be, "the redistribution of power that enables the have-note, prosuntly oxcluded from the folitical and economic process. to be deliberately included in the evture. It is the strategy by which the have-nots join in determining how information is shared, goals anil pulicies iare set, tax resources are allocated, programs are oncrated. and benefits like contracts and patronage are parceled out." 11

Certainly by this definition, the Hudson-Jeffersonjoymour-Petreat Neighbors are not involved in an ideal citizen participation mechanism. n one-way flow of information from Hospital officials to residents, does not provide for a feedback mechanism in order to alter the plannin. function. Rather, this system of participation relies or reacting to already conceived plans, making it much moce difficult to halt possibly harmful proposals.

In crder for the planning process to work effectively and democratjcally, values at all levels have to be considerod otherwise conflict is produced. Mr. Somoza has said trat the needs of the Hospital and the needs of the residents are not consistent, and therefore conflict is inevitable. 12 Fe also said that there are many aspects of blanning that the community does not understand. Viewpoints like that rave given planning a bad name. If the comminity does not undorstand, il 1 i because they have nevir been Ejven a crance to understirid. 
kecommendation \#3

Varying viewpoints, while onzompassing a greater body of knowledge, frovide us with alternative understanding of values that exist at the different levels of soasty. Professional planners are vulnerable to jncompletr olanning because their values, both professional and personal. keal citizen participation, not iust tokenism, may provide i solution to planners' value judgements. Legitimization of the planning process can only be achieved if the planner keeps in mind that he/she is planning for everyone. Flanning that reaches and works for everyone involved will have an easier time in gaining legitimacy. In this light, it is recommended that citizens in the neighborhood be allowed to help in formulating the plans of the Hospital, so that residents can provide the decision-makers with workable solutions. 
Footnotes: Chapter 5

1 "Inside Our Hospitals", U.S. News and World Report (Mar. 5, 1979) p. 33.

${ }^{2}$ Interview with Bill Waters, Director of Health Planning, State of Rhode Island.

"Inside our Hospitals", Op. Cit., p. 34.

${ }^{4}$ Ibid., p. 34 .

${ }^{5}$ Interilew with Don Ingalls, Health Planning Stafe, State of Connecticut.

${ }^{6}$ Interview with Paul Somoza, Director of Planning for Hartford Hospital, April, 1979.

7 David H. Rhinelander, "Director Resighs At Consortium" The Hartford Courant (April 9, 1979) p. 3.

${ }^{8}$ Ibid., p. 8 .

9 Memorandum form Councilperson Meldred S. Torees. Contained in the appendix.

10 Fact sheet obtained from the block club.

${ }^{11}$ Sherry R. Arnstín, "A Ladder of Citizen Participation", The American Institute of Planners Journal ( $\mathrm{J}_{u} l \mathrm{y} 1969$ ) p. 21.

${ }^{12}$ Interview with Paul Somoza. 
Appendix A

A Chronolngy of Communications an Lettera Portaining To This Sturiy 
$\because$ Hartford
$\therefore$ Architecture
$\because$ Conservanity

October 24,1978

Mr. Allan Medoff

City Manager's Office

550 Main Street

Hartford, Connecticut 06103

Dear Mr. Medoff:

With regard to the demolition permits on 151 and 155-157 Retreat Avenue, the Conservancy appreciates the opportunity to comments. These apartment buildings, constructed in 1911 and 1910 respectively, were designed by Hartford architect Burton A. Sellew. Number 151 has been rated "better" and 155-7 "good" on our Historic Building Survey's evaluation, which use a scale of good-better-best-outstanding. While clearly not landmark buildings, they are fine examples of early apartment house design, built in the Neoclassical mode of the day. They appear to be in excellent condition and could provide badly needed housing. Their loss would seriously impact a neighborhood al ready weakened by demolition.

We have discussed these demolitions at length with Hartford Hospital's administration, and have: not been able to convince them to date to keep the structures. Local community organizations have also expressed concern about the demolitions. In view of the widespread concern over these demolitions, in view of the sound condition of the buildings, and in view of the lack of any long-range parking or development plan on the part of the hospital, we urge you not to waive the full 90-day public notice period.

We would further urge that the Manager recommend to Council a resolution calling upon the hospital to reconsider its demolition plans and to seek alternative solutions to its parking problems. We believe that such a recommendation would carry considerable weight and would place the city squarely on record against needless demolition of sound housing. Dur own careful review of the area indicates that there are a number of alternative solutions.

Yours sincerely,

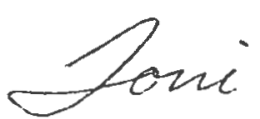

Toni Gold

Executive Director 
j:

Jon Colman, Director,

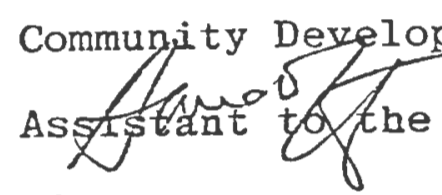
and Planning

20M:

Allan Medoff, City Manager

IBJECT: 151 and 155-157 Retreat Avenue

DATE

November I, 1978

COPY TO: Mr. Sulik

Mr. McSheffery

Ms. Gold, HAC

As we discussed, the City Manager would like you to contact Hartford Hospital and request them to reconsider their plans to construct parking lots in place of the existing buildings situated at 151 and 155-157 Retreat Avenue.

These buildings appear to be in sound condition and could provide badly needed housing, according to HAC which has looked into this matter at our request.

The attached correspondence restates the position of the hospital, HAC,as well as the position of the city to this point.

If it would be helpful, Mr. Sulik is willing to meet with hospital representatives and HAC to strengthen your request.

As the hospital has applied to the city for a waiver of the 90-day waiting period prior to demolition, a timely response is important.

AM: $\mathrm{mlp}$

Attachment 


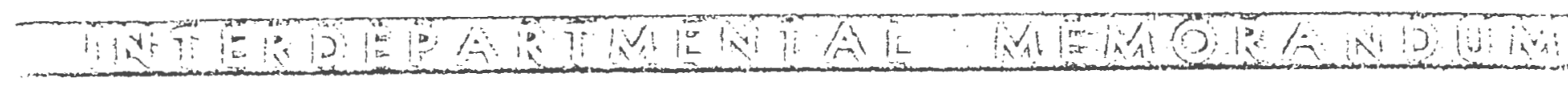

I: Jonathan C. Colman
OM: Eawin P. Williams DATE January 16, 1979
IBJECT: HOUSING AND PARTiG LOTS

Dewayne and I are very distiessed about present actions of Hartford Hospital in tearing dom two fine apartment buildings on Retreat Avenue in order to construct a parking lot. This parallels similar actions taken by St. Francis Hospital over the past Few years.

There are several issues involved here, including the expansion of hospitals, the spread of tax-exertpt property and parking policy.

I would like to know what alternatives, if any, have been considered by the City in the past to prevent these kinds of actions from happening.

Possible actions that come to mind $\lambda$ include:

$$
\begin{aligned}
& \text { which we may went to consider indeing } \\
& \lambda \text { include: }
\end{aligned}
$$
- placing controls on the purchase and use of land by tax-
exempt organizations.

- placing controls on the expansion of hospitals.

- coordinated health planning among hospitals to mininize duplication of services and consolidate growth plans.

- greater City input in the growth plans of hospitals and other tax-exempt organizations.

If you 100k at NDI maps over time, the spread of green land area (pibiic, tax-exempt) is increaible and frightening. If this continues unabated, Hartford's tax base will continue to erode and the loss of good housing will increase.

EPT/Cd 
FOR THE PAST SIX MONTHS, WE THE SEYMOUR-JEFFERSON-HUDSON-RETREAT NEIGHBORS HAVE BEEN MEETING VITH MR. PAUL SOMOZA, PRESENTLY THE PLANNING DIRECTOR FOR HARTFORD HOSPITAL. IN THAT TIME WE HAVE BEEH TOTALLY CCLFESSD BY HIS VAGUE ANSWERS, MIS-IIFORMATION AND MON-SUPPORT OF OUR PROBLEMS AND NEEDS. AT THIS POINT HE HAS REFUSED TO MEET VITH US, AND HAS REFUSED TO SET UP A MEETIIG UITH THE BOARD .OF DIRECTORS OF HARTFORD HOSPITAL.

"We have no future: plans for the neighborhood. Its not our neighborhood, and we shouldn't be planning for it."

(Paul Somoza, Planning Director Hartford Hospital, Oct. 1978) Southside Nelghborhood News

YET :

-In January the hospital demolished 151-155-157 Retreat Ave., a loss of 21 units of housing and a los of over $\$ 8,000$ in taxes.. The Hospital owns over $\$ 30$ million worth of tax exempt property. -On January 21, 1979, the Hospital purchased 11 Seymour St. and has told one of the six tenants they'will all be evicted by April l:The Hospital has stopped all maintenance on the building. They plan to demolish 11 Seymour St.

-The Hospital has yet to tell the neighborhood if it plans to rehabilitate or demolish 98 Jefferson St. since they evlcted its tenants.

-A model of the Hospital's future plans for the nelghborhood reveals more parking lots and the closing of Seymour St: WE WANT THE HOSPITAL'S PLANS FOR THE NEIGHBORHOOD OUT III THE OPEN. THE SEYMOUR-JEFFERSON-HUDSON-RETREAT NEIGHBORS WANT TO BE TUVOLVED IIV THE PLAITIING PRCCESS FOR OUR INEIGHBORHCOD. TE ARE SENDING AN OPEN IETTER TO THE BOARD OF DIRECTORS OF HARTFORD HOSPITAL TO REQUEST AN OPEN MEETING TO DISCUSS THESE CONCERNS. 


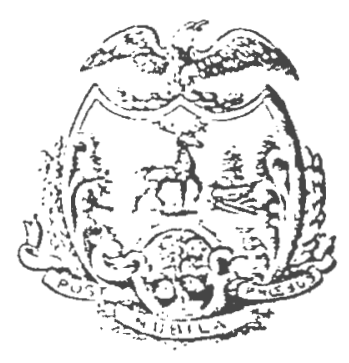

Councilmen

Nicholus R. Carbune

Willism At Dibelta

Silney L. Gardnee

Rubere F. Ludgin

Raymund Alunteiro

Richord Suisman

Margaret $V$. Tedune

Olyd WV. Thompson

Mildred S. Torres

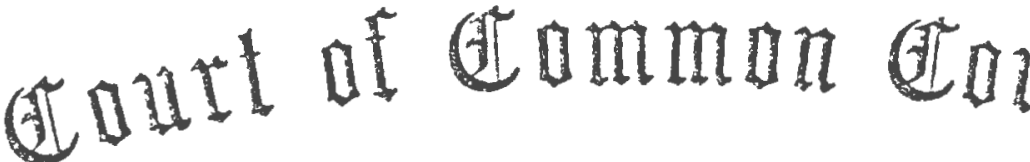

CITY OF HARTFORD

550 MAIN STREET

HARTFORD, CONNECTICUT 06103

This is to certify that at a recessed meeting of the court of comnon Council, Febmuary 16, 1979, the following RESOLUiIOis was,passed.

HrHeREAS, Expansion of najor institutions can have a najor inpact on adjacent neighborhoods; and

WEEREAS, Some institutions in Hartford such as hospitals and colleges have recently made physical development decisions of significant inpact on neighborhoods near these institutions; and

WHEREAS, Cities such as San Francisco and Boston have adoptedvarious procedures to insure that institutional expansion does not have negative impact, such as ordinances requiring institutional naster plans governing expansion and zoning for new uses; now, therefore, be it

RESOLVED, That the City Manager and the Comnission on the City Plan be requested to investigate the use and effectiveness of these and other tools as to their applicability to Hartford's neighborhoods and institutions.

Attest:

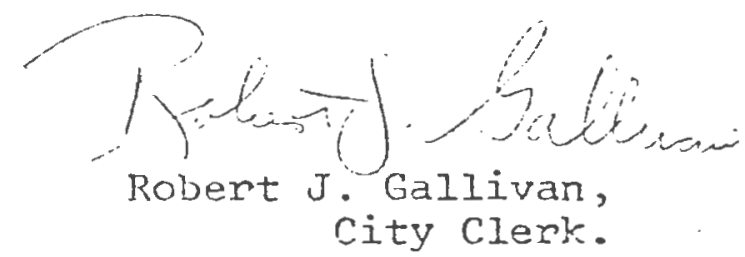

Copias to: City Manager, City Plan Comission, and Director of Public Work 


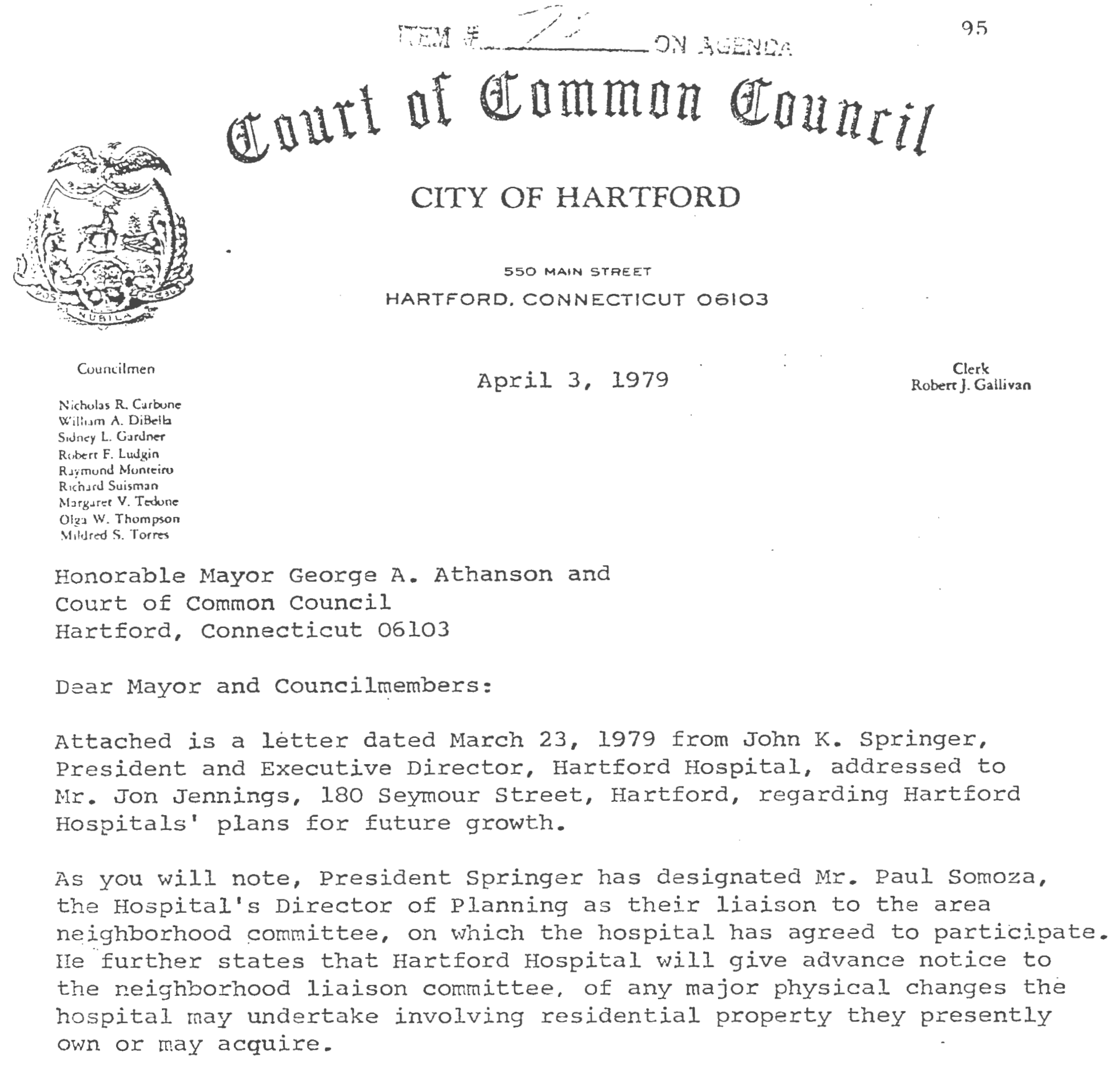

The attached is for your information and referral to the Education, Public Safety and zoning Comunity for appropriate follow-up.

Respectfully submitted,

NRC; cf

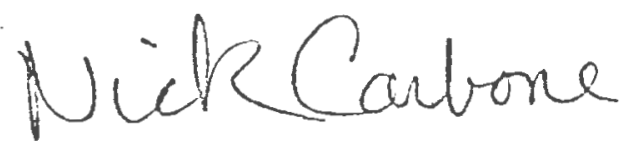

Enc.

Nicholas R. Carbone

Deputy Mayor 


\section{6 \\ RECEIVED \\ IARR $\approx 91979$ \\ CITY COUMECIL OFFICE

JOHN K. SPRINGER

PRESIDENT ANO EXECUTIVE DIAECTOR

March 23, 1979

Mr. Jon Jennings

180 Seymour Street

Hartford, Connecticut 06105

Dear Mr. Jennings:

We have received your March 22, 1979 letter to the Executive Comittee of Hartford Hospital's Board of Directors. It stresses the neighborhood's desire to be apprised of the hospital's plans, both present and future.

During our March 13 meeting, I made two comitments to the neighbors, namely, an agreement to notify you in advance of any major physical changes involving residential property we may own or acquire, and our agreement to participate in a neighborhood liaison comittee. .

Given these agreements, we do not believe any substantial purpose would be served by yet another meeting. I am appointing Mr. Paul Somoza, our Director of Planning, to represent the hospital on the liaison comittee. He will kbep me, and through me, the Executive Comittee of the Board, apprised bE your discussions and concerns.

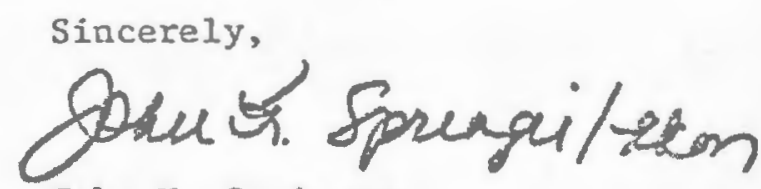

John K. Springer

JkS:kksn

cc: Mr. Jc:aph h. Saregent

City Councilv

Mr. Jon Coleman, City Planning Dept.

Mr. Paul P. Somoza 


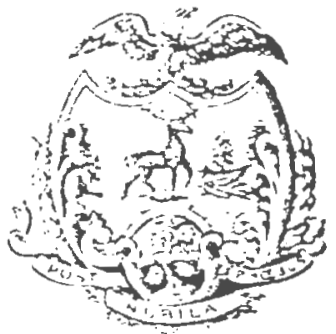

Cunvilmen

Nichulds R Carbune

William A Dibelt

Silney L. Gardner

Rubere F. Lutgin

Rujmond Munreiru

Richurd Suisman

Murgiser V. Tedune

Oles Wh. Thompon

Mildred S. Torres

Honorable Mayor and

Court of Common Council

Hartford, Connecticut

Dear Mayor and Councilmembers:

Your Education Public Safety and Zoning Committee held a meeting on Monday, April 2, 1979 to discuss a communication from Deputy Mayor Carbone de residents concerns over Hartford Hospital's influence on the neighbornood.

In the communication submitted to council the residents of the neighborhood stated that in the past they feel that their livelihood and future has been totally influenced by the existence of the hospital. This feeling, coupled with recent developments, has put them in such a position where they not only want to know what the hospital plans, but they also insist that they should become part of the planning process.

The members of the Block club stated that the hospital has given them very little support in their efforts to preserve the neighborhood. The group stated that the hospital has continuously refused to support their effort to obtain better police protection, traffic control, and street lighting for the neighborhood. The residents are also concerned about the hospital acquisition and demolition of surrounding residential property.

The members of the Block club stated that they recently held a meeting with several representatives from the hospital in order to discuss their concerns. They stated that the meeting was not a very succesful one. The hospital refused to make any firm commitments to the group and also the hospital will not reveal their future plans for expansion. paul Somoza from Hartford hospital stated that at the present time the hospital has no imnediate plans for expansion. He stated that the Block club members were told this at the meeting, but still refuse to accept it as the truth. Your comnittee chairwoman suggested that perhaps if the hospital put this in writing the residents might be more willing to accept it. Mr. Somoza stated that he feels it is not necessary to put it in writing. 
Honorable Mayor and

Court of Common Council

Page Two

One positive outcome of the meeting was that the hospital agreed to meet with a liaison group from the neighborhood to discuss any future plans for expansion. The liaison group has not been formed as yet but they expect it should be formed in about 2 weeks. It should be noted that the liaison group will not have direct input into the planning process but instead the hospital will present completed plans to the group for review.

Jon Colman stated that primary problem that the hospital and residents has is one of credibility. and cooperation. He stated that it is very difficult for the residents to trust the hospital because of the actions that the hospital has taken in the past. He stated that it is imperative that the hospital representative and residents work together to resolve their differences. In addition he stated that city staff would be willing to work with the residents to put together a viable liaison group. Mr. Colman also stated that he has a good Faith understanding with the hospital that no demolition or further acquisition of properties will take place in the interim before the liaison is formed.

Your Education, Public Safety and Zoning Committee will meet again in 4 weeks after the liaison group is formed to discuss this item further.

Your Committee Chairwoman submits this as an interim report and requests that it be received and placed on file.

Respectfully Submitted

Education, Public Safety \&

zoning Committee

Mildred Torres, Chairwoman

$M T: 1$ 
Ampondix B

Table of Tax-Exempt Property Owner by the Hosnital 
1977 CURREIT TAX LIST

REAL ESTATE--TAXAELE

HARTFORD FOSPITAI

ADLRESS

482-488 पludson St. 94-96 Jefferson St. 143-145 Jefferson St.

149 Retreat Ave.

151 Retreat Ave

155-157 Retreat Ave. 46 seymour St.

9 Seymour.:- St.

21 Seymour St.

32-36 Seymour St.

268-270 Washington St.

282-284 Washington St.

11 Seymour St.

42 Seymour .St.

1977 CURRENT TAX LIST

TAX EXEMPT PROPERTY

HARIFORD HOSFITAL

ADDRESS

560 Hudson St.

143-145 Jefferson St.

155-157 Retreat Ave.

80 Seymour St.

31 Seymour St.

256 Washington St.

258 Washington St.

260 Washington St.

268-270 Washington St.

282-234 Washington St.

TOTAL
VALUATION

$\$ 2,380$

34,900

24,480

7,390

48,640

46,690

10,420

10,140

39,680

21,290

5,890

45,390

$\$ \overline{297,290}$
TAX DUE

$\$ 216.32$

$3,172.40$

$2,225.20$

671.72

$4,421.36$

$4,244.12$

947.16

921.72

$3,606,88$

$1,935.24$

535.40

$4,125.92$

$\$ 27,023.44$
ASSESSED VALUE

$$
\begin{array}{r}
\$ 3,747,170 \\
49,710 \\
25,960 \\
25,155,120 \\
1,558,810 \\
42,250 \\
10,540 \\
31,000 \\
67,720 \\
181,560 \\
\hline
\end{array}
$$

TAXABLE VALUE

$$
\begin{array}{r}
\$ 40,617.75 \\
4,518.63 \\
2,359.76
\end{array}
$$$$
2,286,600.40
$$$$
141,695.82
$$$$
3,840.52
$$$$
958.09
$$

$2,817.90$

$6,155.74$

$16,503.30$

$\$ 2,806,068.41$.

JEFFERSON ST . NEDICAL BUILDING INC. REAL ESTATE-TAXABLE

\section{ADDRESS}

75-95 Jefferson St. 127 Jefferson St. 100-98 Jefferson St.
VALUATION

$2,884,030$

707,680

$\$ 3,591,710$ 


\section{BIBLIOGRAPHY}

American Hospital Association, Major Federal Aid Programs for Hospitals (American Hospital Association, Chicago, 1970)

Arnstein, Sherry if., "A Ladder of Citizen Participation", The American Institute of Planners Journal (July 1969)

Courtney, Pat, "Hospital Parking Pressures Neighborhood", Southside Neighborhood News (Oct. 18- Nov. 1, 1978)

Department of Commuity Planning and Development, City of Hartford: Housing Policy and Anti-Displacement Action Program (war. 1979)

Downs, Anthony, Urban Problems And Prospects (Markham Publishing Co., Chicago, 1971.)

Doxiadis Associates, Inc., The Trinity Community: Feasability Studies for Area Improvement (Washington D.C., Mar. 1967)

Fried, Marc, "Functions of the Working Class Community in Modern Society: Implications for Forced Relocation": American Institute of Planners Journal. (Vol. 33, No. 2)

Gans, Herbert, People and Plans: Essays on Urban Problems and Solutions (Basic Books, New York, 1968)

Ginzberg, El1, The Limits of Health Reform (Basic Books, New York, 1977)

Gray, Lovett 8.,"Banks Snub Apartment Houses", The Hartford Courant (Mar. 25, 1979)

Hartfian, Chester, "The Politics of Housing: Displaced Persons", Society Magazine (July/Aug., 1972)

"Inside Our Hospitals", U.S. News and World Report (Mar. 5, 1979)

Lave, Judith R., and Lave, Lester B. F The Hospital Construction Act: An Evaluation of the Hill-Burton Program, 1948-7973 (American Enterprise Institute for Public Policy Research, Wakhington D.C., 1974)

Pappas, Nancy, "Hospital Parking Solution Out of Sight", The Hartford Courant (Oct. 29, 1978)

Pechman, Joseph, editor, Setting National Prtorities: The 1979 Budget (Brookings Institute, Washington D.C., T978) 
Rhinelander, David H. "Director Reaigns At Consortium", The Hartford Courant (April 9, 1979)

Sevick, Stephanie, "Deterioration Seen Displacing Poor", The Hartford Courant (April 1, 1979)

Smith, Larry, adnd Associates, GGuide Report For Commercial and Industrial Renewal (New York, N.Y. , 1964)

Sternlieb, George, and Burchell, Robert W., Residential Abandonment: The Tenement Landlord Rbvisited (Center for Urban Policy Research, Rutgers University, New Brunswick, N.J., 1973)

Waitzkin, Howard, and Sharratt, John A., "Controliing Medical Expansion", Seclety Magazine (Jan/Fob., 1977)

Wilson, James Q., editor, Urban Renewal: The Record and the Controversy (M.I.T. Press, Cambridge, 1966) 